\title{
Does Short Selling Discipline Managerial Empire Building?
}

\author{
Eric C. Chang ${ }^{\mathrm{a} *}$ Tse-Chun Lin ${ }^{\mathrm{a} \dagger}$ Xiaorong Ma ${ }^{\mathrm{a} \ddagger}$ \\ $a_{\text {Faculty of Business and Economics, University of Hong Kong }}$
}

\begin{abstract}
This paper explores the discipline effect of short selling on managerial empire building. Employing short-selling data from 2002-2011, we document a negative association between the stock lending supply and the subsequent abnormal capital investment. We also find a positive association between the lending supply and the mergers and acquisitions announcement returns of acquiring firms. Firms with higher lending supplies also have higher Tobin's Q in the subsequent year. In addition, the discipline effect is stronger for firms with higher managers' wealth-performance sensitivity and with lower financial constraints, and for stock-financing acquisition deals. Alleviating the endogeneity concern, our multivariate difference-in-difference analysis shows that the lending supply is a more effective discipline force for firms that are in the Regulation SHO-Pilot Program during 2005 to 2007.
\end{abstract}

JEL classification: G10, G20, G30.

Keywords: short selling, empire building, governance, mergers and acquisitions, Regulation $\mathrm{SHO}$

We have benefited from the comments of Lauren Cohen, Sandy Lai, Erica X.N. Li, Alexander Ljungqvist, Ernst Maug, Kelsey Wei, Hwang Chuan Yang, and Hong Zhang. We also appreciate helpful comments from seminar participants at University of Hong Kong, Hong Kong University of Science and Technology, and National Central University. We gratefully acknowledge the research support from the Faculty of Business and Economics at the University of Hong Kong and the Research Grant Council of the Hong Kong SAR government. Any remaining errors are ours.

${ }^{*}$ Tel.: +852-2219-4567. E-mail address: ecchang@hku.hk

${ }^{\dagger}$ Contact Author: Tel.: +852-2857-8503. E-mail address: tsechunlin@hku.hk

†ंTel.: +852-6841-4405. E-mail address: xrma@business.hku.hk 


\section{Introduction}

"It is quite clear that one way for a company to steer a course through the jungle is to be well-run and soundly governed. Then the speculators are more likely to leave you alone. Short sellers look for weakness and when they find it, they act."

(Peter Montagnon, chairman of the International Corporate Governance Network, 2008)

Since U.S. Securities and Exchange Commission announced short selling bans during the 2008 financial crisis, the perennial debate on the role of short sellers has been brought back. On the one hand, regulators contend that short sellers could harm financial markets by driving stock prices below their fundamental values and dampen the investor confidence. ${ }^{1}$ On the other hand, a large body of literature has shown that short sellers are informed traders, and their trading activities help to incorporate information into stock prices. For instance, short sellers can identify not only low future stock returns (e.g., Asquith, Pathak, and Ritter (2005); Boehmer, Jones, and Zhang (2008); Engelberg, Reed, and Ringgenberg (2012)), but also adverse financial reporting, such as negative earnings (Christophe, Ferri, and Angel (2004)), financial misrepresentation (Karpoff and Lou (2010)). Besides, Jensen (2005) argues that “...Short sellers are an obvious source of potentially valuable information for the governance system..." However, little research has been conducted on this potential governance effect of short sellers. Our paper fills the void of literature by investigating whether short sellers have discipline effect on managerial empire building, one of the most value-

\footnotetext{
${ }^{1}$ In the order enacting the short-selling restrictions in 2008, SEC states that "...is in the public interest and for the protection of investors to maintain or restore fair and orderly securities markets. This emergency action should prevent short selling from being used to drive down the share prices of issuers even where there is no fundamental basis for a price decline...". Meanwhile, two academic studies advocate similar points of view. Goldstein and Guembel (2008) hypothesize that short sellers might manipulate stock prices, which results in bad managerial investment decision. Henry and Koski (2010) show that the levels of pre-issue short selling volume are positively related to abnormal returns on the SEO announcement date, suggesting that short sellers engage in manipulative trading.
} 
destroying agency problems. ${ }^{2}$

The intuition that the short selling can serve as an external corporate governance mechanism is as follows. Short sellers have been shown to be able to identify managerial misbehaviors and unfavorable information that have not been reflected in stock prices, e.g., Bris, Goetzmann, and Zhu (2007) and Chang, Cheng, and Yu (2007). The downward price pressure due to short selling would damage managers' personal interests via reduced stock-based compensation and increased likelihood of a hostile takeover, which might result in the subsequent job loss. Hence, the presence of an active short selling market could serve as an external governance mechanism on managerial behavior and deter managers from engaging in value-destroying activities ex ante. Empirically, we examine the discipline effect of short selling on firms' abnormal capital investments and mergers and acquisitions announcement returns of acquiring firms in the subsequent year.

The effectiveness of aforementioned discipline mechanism hinges on the number of shares available to the short sellers. Short sellers would have less incentive to search for weakness of firms if they cannot easily borrow shares to short. We use the lending supply in the short selling market to capture the amount of ammunition that the short sellers can use to profit from spotting the managerial value-destroying over-investments. ${ }^{3}$ The higher the lending supply, the more severe the punishment managers face through the short-selling-induced price pressure once their misconducts get caught. Relying on this measure, we are able to test our main hypothesis that short selling has a discipline effect on managerial empire building.

To support our hypothesis, we conduct three sets of tests. First, we examine whether the discipline force of short selling affects the frequency of large investments. Whited (2006) proposes a

\footnotetext{
${ }^{2}$ Richardson (2006) suggests that entrenched managers have a greater tendency to build up empire.

${ }^{3}$ We use the value of shares supplied for lending, reported by Markit, scaled by firm's market capital as the measure for lending supply, same as Saffi and Sigurdsson (2011) and Massa, Zhang, and Zhang (2012).
} 
hazard model to measure the magnitude of empire building by focusing on the frequency of investment spikes (large investments) and the time between spikes (spells). She argues that the hazard model could address concerns of measurement errors in instruments for investment opportunities and lumpy characteristics of corporate investments. ${ }^{4}$ Using the lending supply data from 2002 to 2011, we find that a firm with higher lending supply has less empire building behavior, exhibited by a lower hazard rate and a longer spell between investment spikes. In particular, we find that a one-standard-deviation increase in lending supply leads to $20.47 \%$ decrease in the hazard rate.

Second, we investigate the discipline effect of lending supply on abnormal capital investments, the difference between the current capital investment and the average capital investment in the previous three years, a measure for empire building in Titman, Wei, and Xie (2004). Controlling for a set of firm-specific variables including institutional ownership ratio, E-Index, firm size, sales growth, leverage and influences from the effects of year and firm, we find that firms with higher lending supply have lower subsequent abnormal capital investment. A one-standard-deviation increase in lending supply results in $63.35 \%$ lower abnormal capital investment in the following year. This set of evidence indicates that lending supply in the short selling market would deter managers from making abnormal capital investments.

Our third set of analysis focuses on mergers and acquisitions, which is a much larger and easier observable form of corporate investments. Literature has shown that managers may conduct value-destroying acquisition to expand the size and scope of the firms rather than return cash to shareholders (Jensen and Meckling (1976); Masulis, Wang, and Xie (2007); Chen, Harford, and Lin (2012)). We examine a sample of around 1,000 completed U.S. domestic mergers and acquisitions

\footnotetext{
${ }^{4}$ Employing the hazard model method, Billett, Garfinkel, and Jiang (2011) find that firms with more antitakeover provisions will experience shorter spell lengths between large investments, suggesting that managers at firms with less shareholder governance will engage in over-investment more frequently. Besides, Chang, Lin, and Ma (2012) find that firms with more intensive institutional trading have smaller hazard rate of over-investment, indicating the discipline effect of institutional trading on managerial empire building.
} 
between 2003 and 2012 and find that acquirers with higher lending supply in the previous year yield higher announcement returns. After controlling for total assets, past stock returns, return on asset, Tobin's Q, fixed asset, R\&D, Non-cash working capital, leverage, free cash flow, relative deal size, dummy of friendly deals, dummy of high-tech deals, dummy of tender offers, dummy of cash deals, and institutional ownership ratio, we find that a one-standard-deviation increase in lending supply leads to $8.13 \%$ standard deviation increase in five-day cumulative abnormal returns. The results suggest that managers in firms with high lending supply have less tendency to conduct valuedestroying acquisitions. Collectively, these three sets of results are consistent with our hypothesis that short selling has a discipline effect on managerial empire building.

Next, we investigate whether the discipline force of short selling has effect on the firm value. We hypothesize that lending supply is positively associated with firm value in the subsequent year as the value-destroying empire building is disciplined. Relying on a sample of about 20,000 firm-year observations, we find that firms with higher lending supply have higher Tobin's Q in the subsequent year. A one-standard-deviation increase in lending supply results in an increase of $3.89 \%$ standard deviation in the subsequent firm value.

To further substantiate our argument, we first examine the effect of managers' compensation on the association between the lending supply and the subsequent managerial empire building. Specifically, we use the scaled wealth-performance sensitivity (ScaledWPS), proposed by Edmans, Gabaix, and Landier (2009), to measure the sensitivity of the manager's wealth to stock price. Because it is the threat of downward price pressure due to short selling that deters managers from empire building, the effectiveness of the discipline mechanism depends on the sensitivity of managers' wealth to stock price. Indeed, we find that the negative association between the lending supply and the hazard rate is more prominent for firms with higher ScaledWPS. We also find that the 
associations between lending supply and the subsequent abnormal capital investment and Tobin's Q are more evident in firms with higher ScaledWPS. For the acquisition announcement returns, the discipline effect is only significant for firms with high ScaledWPS. This set of results strengthens the interpretation that the negative association between lending supply and overinvestment is rooted in the discipline force on managerial behavior.

In addition, we use the HP index, proposed by Hadlock and Pierce (2010), to gauge the extent to which financial constraint levels influence the discipline effect of lending supply. It is intuitive that managers in financially constrained firms are less likely and able to build up empire for their private benefits (Whited (2006); Billett et al. (2011)). If the lending supply has discipline effect on empire building behavior, it should be more significant for firms with less financial constraints. The results do show that the discipline effect on hazard rate of investment spikes and abnormal capital investment is stronger for firms with lower HP index (less financially constrained firms).

Moreover, we find that the effect on acquisition announcement returns is only significant in non-all-cash-financed acquisitions. ${ }^{5}$ This is consistent with the notion that managers tend to build up empires in stock-financed deals (Fu, Lin, and Officer (2013)), in which the discipline effect of lending supply on managerial behavior would manifest. The results also indicate that the positive association between lending supply and the subsequent Tobin's Q is more pronounced for firms with high ScaledWPS and low HP index, which is in line with our hypothesis.

Even though the previous cross-sectional analyses on managerial compensation and financial constraints help to pin down the mechanism of the discipline effect, the endogeneity issue can still be a concern. One may argue that lenders in the short selling market, i.e., ETFs or index funds, might also have information regarding the future managerial behaviors. They may increase lending

\footnotetext{
${ }^{5}$ The all-cash-financed deal means the method of payment is $100 \%$ cash according to SDC database.
} 
supply when the manager is expected to have good performance, and vice versa. If this is the case, the negative relation between lending supply and abnormal capital investment and the positive relation between lending supply and firms value might reflect the information held by the supply side (lenders) in the shorting market rather than governance role of short seller (the demand side of the lending market). Although it is less likely that ETFs and index funds, typical passive investors, would actively collect firm specific information, we conduct two sets of tests to address this issue. First, we employ a regulation change in U.S. equity markets, i.e., the Regulation SHO. The price restriction of short selling (the uptick rules) for a set of randomly selected firms is lifted from January 2005 to August 2007. We adopt the multivariate difference-in-difference methodology in this quasi-natural experiment setup and find that the lending supply has stronger discipline effect for firms that are exempted from the uptick rules. This result provides coherent evidence that short selling takes role in corporate governance, and its discipline force is more effective when short selling is less restricted.

Second, we use the residual term from the lending supply regressing on firm size, book-tomarket ratio, firm age, institutional ownership ratio, and turnover ratio as the main independent variable. ${ }^{6}$ We re-estimate all our major regression models using the residual lending supply and show that our main results still hold. These results suggest that our main findings are not driven by the effects stemmed from institutional investors or other firm characteristics, and further support that lending supply is a proxy for the governance mechanism from short sellers.

Our paper contributes to two burgeoning strands of literature. First, our study differentiates and complements two contemporaneous studies of Massa et al. (2012) and Fang, Huang, and Karpoff (2013) in providing evidence on the discipline effect of short selling. Massa et al. (2012) find a

\footnotetext{
${ }^{6}$ Saffi and Sigurdsson (2011) show lending supply is closely related to firm size, book-to-market ratio, and turnover ratio.
} 
negative relationship between lending supply and earnings manipulation over the period of 2002 to 2009 across 33 countries. Fang et al. (2013) find that discretionary accruals decrease for the treated firms in the Regulation SHO-pilot program. While both papers study the discipline effect of short selling on the accrual-based earnings management, we focus on the managerial empire building, i.e., inefficient corporate over-investment. The reason that our paper focuses on managerial empire building is because we believe that the empire building destroys firm values more directly than financial reporting distortion. In addition, our empirical evidence suggests that the discipline effect of short selling pertains more to the overinvestment than to the "quiet life" hypothesis (Bertrand and Mullainathan (2003)). This might be because it is easier for short sellers to spot and target managers in firms exhibiting propensity for empire building than enjoying the quiet life. Second, our paper is also related to and expands the literature on the real effect of financial market (Bond, Edmans, and Goldstein (2011); Chen et al. (2012); Edmans, Goldstein, and Jiang (2012); Hau and Lai (2012)). We provide evidence that the lending market condition could impact managerial real resources allocation decisions.

The remainder of the paper is constructed as follows. Section 2 presents literature review. Sections 3 includes the description of the data and sample. Section 4 shows the measures and empirical results. Section 5 includes the additional tests. Section 6 concludes.

\section{Literature Review}

\subsection{The Role of Short Sellers}

Prior literature on the role of short sellers suggests that the informational efficiency of stock prices is improved when short sellers are more active. ${ }^{7}$ In Dimond and Verrecchia's (1987) model, the

\footnotetext{
${ }^{7}$ See, for example, Diamond and Verrecchia (1987), Bris et al. (2007), Chang et al. (2007), Boehmer et al. (2008), and Boehmer and $\mathrm{Wu}(2012)$.
} 
presence of short sellers speeds up the incorporation of private information into stock prices. By analyzing 46 equity markets around the world, Bris et al. (2007) provide evidence that short sales restrictions hinder the quick and accurate reflection of value-relevant information in the stock market. Focusing on one market, Hong Kong, Chang et al. (2007) identify the events when stocks are added to designated short-sale list, and show that short-sales constraints are likely to result in overvaluation. By using daily short selling data of NYSE-listed firms, Boehmer et al. (2008) show that heavily shorted stocks underperform lightly shorted ones, suggesting that short sellers play a role in improving pricing efficiency. Boehmer and Wu (2012) complement Boehmer et al. (2008) by examining the association between daily short sales and four specific measures of information efficiency. They provide supportive evidence that the presence of short sellers helps price efficiency.

Prior literature has also shown that short sellers could anticipate managerial misconducts. Christophe et al. (2004) find that the daily short sales in the five-day prior to earnings announcement are negatively correlated with post-earnings-announcement stock returns, suggesting that short sellers could predict a negative earnings surprise and a lower stock returns. Desai, Krishnamurthy, and Venkataraman (2006) find that the difference in short interests between restatement firms and control firms increases significantly from 18 months before the announcement, and then started to shrink at one month after the announcement, indicating that short sellers could identify suspicious financial reports in advance of public release. Karpoff and Lou (2010) find that the short interests accumulate gradually from 19 months in advance of the public revelation of the financial misrepresentation, indicating that short sellers could detect both the occurrence and the characteristic of the managerial misconducts.

These studies focus on how short sellers could improve price efficiency and discover managerial misbehaviors. Based on these works, we go one step further and ask whether informed and vigilant 
short sellers could server as a discipline force. Specifically, we add to this stream of literature by testing whether managers will be less likely to engage in empire building when more shares can be borrowed by short sellers, as managers would be afraid of the reduction in personal welfare brought by severe short-sales if their misbehaviors get detected.

\subsection{Empire Building}

Jensen (1986) argues that "...Managers have incentives to cause their firms to grow beyond the optimal size. Growth increases managers' power by increasing the resources under their control." To gauge the empire building based on the frequency of large investments, Whited (2006) develops an empirical methodology based on hazard model estimation. Hazard model mitigates the potential measurement errors in the usual proxy for investment opportunities, such as Tobin's Q. Whited shows that more financially constrained firms tend to experience longer inactive "spells" between larger investments ("spikes"), suggesting a lower hazard rate of large investment. Based on the Whited's (2006) methodology, Billett et al. (2011) examine the effect of antitakeover provisions, "G-Index" of Gompers, Ishii, and Metrick (2003), on managers' tendency to over-invest. They find that the hazard rate of well-governed firms lies below that of poor-governed ones, suggesting that good governance hinders managers from over-investing.

Additionally, Titman et al. (2004) use the last three-year average capital investments to gauge the benchmark of firm's investment rate, and define the abnormal capital investment (CI) as the difference between the current year's capital investment and the benchmark. They show that the negative association between the CI and the consequent abnormal stock return is more prominent when firms have more free cash flow and lower leverage ratios and when hostile takeovers are less likely to occur, suggesting that investors tend to underreact to the value-destroying implication for 
an increased CI (empire building).

Existing literature has shown that mergers and acquisitions, much larger and more easily observable corporate investments, would also be used by managers to extract their own benefits. Masulis et al. (2007) show that managers at firms with more antitakeover provisions tend to initiate acquisition deals that hurt shareholders, reflected by a lower abnormal announcement return. It suggests that antitakeover provisions would shield managers from the discipline effect of the market of corporate control, and thereby lead to managerial value-destroying empire building. Employing the natural experiments of the drops in analysts coverage, Chen et al. (2012) document that managers at firms experiencing exogenous decrease in analyst coverage are more likely to engage in acquisition deals with lower announcement returns. It suggests that analysts undertake a monitoring role of managerial behaviors and deter managers from conducting value-destroying acquisition deals.

Our paper contributes to this line of research by examining how lending supply affect both the capital investment and the announcement stock returns of acquirers. We document a new external corporate governance mechanism on the the value-destroying managerial empire building.

\section{Data}

We use equity lending supply from Markit, a research company that provides equity lending data collected from security lending desks of most large firms in short-selling market. This dataset includes firm-level information regarding the number of shares available for lending, lending transactions, and weighted average loan fee, and covers from 2002 to 2011. Besides, we obtain stock price, stock return, and number of shares outstanding from Center for Research in Security Prices. Relevant accounting data is from COMPUSTAT. Institutional ownership is from Thomson-Reuters 
Institutional Holdings (13F) Database.

In addition, we obtain acquisitions sample from the Securities Data Corporations (SDC) U.S. Mergers and Acquisitions database. We impose the following restrictions ${ }^{8}$ : (1) The acquisition is completed; (2) The acquiring firms should have less than $50 \%$ of target firms' shares before the acquisition, and own more than $50 \%$ of target firms' shares after the acquisition; (3) The deal is included in our sample if the deal value disclosed in SDC database is more than $\$ 1$ million and more than $1 \%$ of the market value of acquirer; ${ }^{9}$ (4) The acquirer firm should have corresponding financial information in COMPUSTAT; (5) The acquirer should have daily stock return data in CRSP at least 100 days before the announcement; (6) The acquirer could find matching data in the lending supply data. The imposition of these restrictions results in a final sample of around 1,000 U.S. domestic mergers and acquisitions from 2003-2012.

\section{Measures and Main Empirical Tests}

\subsection{Lending Supply Measure}

Following Saffi and Sigurdsson (2011) and Massa et al. (2012), we construct lending supply (LS) as the ratio of the value of shares available for lending to firm's market capitalization. Since abnormal capital investments are calculated annually, we compute the lending supply for firm $i$ in year $t$ based on the annual average of the value of shares available for lending. ${ }^{10}$ In Table A-1, we presents the determinants of lending supply. Consistent with Saffi and Sigurdsson (2011), we also find firms with higher book-to-market ratio and liquidity tend to have higher lending supplies. ${ }^{11}$ More importantly,

\footnotetext{
${ }^{8}$ The application of these filters is following Masulis et al. (2007) and Chen et al. (2012).

${ }^{9}$ Market value of acquirer is calculated as (total asset - common equity + common shares outstanding $\times$ fiscal year end stock price).

${ }^{10}$ Markit provides weekly data after 2004 and daily data after 2006 , we therefore use the average monthly, weekly or daily data to estimate the annual average value of shares available for lending. We then scale the value by firm's market capitalization.

${ }^{11}$ Coefficients on market size are positive before we control for the effect from institutional ownership ratio.
} 
we find that the institutional ownership ratio (IOR) is the most significant determinant of the number of loanable shares in the equity lending market. ${ }^{12}$ To show our results are not driven by the level of IOR, we control for it in all of our main tests.

\subsection{Hazard Estimation}

In this section, we carry out the hazard model estimation for the empire building. The detailed procedure is discussed in Appendix A. Following Whited (2006) and Billett et al. (2011), we also focus on the subsample of small firms. Whited (2006) argues that large firms are more likely to have different business segments, which could help firms to smooth investment, and thereby reduce the hazard rate. She thus only keeps small firms to mitigate this issue. We define small firms as firms whose total asset is below the 33rd percentile of the total assets of all firms in the 1st year that the firm includes in our sample. Besides, in order to capture whether an investment spike occurs for a firm in a certain year, we define the investment spike as four different thresholds, namely 2 or 2.5 times the firm's own median Investment/Assets ratio and 2 or 2.5 times the industry median value in that year. ${ }^{13}$ In particular, we perform the hazard model estimation as follows:

$$
\lambda_{i}(t)=\omega_{i} \lambda_{0}(t) \exp \left(L S_{i, t} \cdot \gamma+x_{i}(t)^{\prime} \cdot \beta\right)
$$

where $x_{i}(t)$ represents a vector of covariates which identifies observable differences across individual firms, and includes two-digit industry dummies, year dummies, ratio of cash flow to assets, sales growth, the logarithm of total asset and leverage ratio. The firm characteristic variables are calculated between the current and previous spikes. The discipline effect of short selling predicts

\footnotetext{
${ }^{12}$ Most of the suppliers of loanable shares are institutional investors, especially ETF and index mutual funds.

${ }^{13}$ We impose restrictions that we have more than three observations both in the industry-year and firm-year.
} 
that the coefficient of LS $(\gamma)$ should be statistically negative, indicating that high lending supply would reduce the hazard rate and extend the duration between large investments.

Table 1 reports the summary statistics for the sample firms included in hazard model estimation. In Panel A, we summarizes the mean, median, and standard deviation of firm characteristics, including investment/assets ratio, lending supply, leverage ratio, cash flow, sales growth and the logarithm of the total assets. The average value of investment/assets is 0.04 with a standard deviation of 0.07 . The mean value of LS is 0.06 with a standard deviation of $0.06 .{ }^{14}$ In Panel B, we reports the mean, median, and standard deviation of spell characteristics. In particular, this sample set includes 1,219 spells, and the average spell length between two investment spikes is 3.48 years.

Table 2 presents the results of hazard model estimation. In columns (1) and (2), an investment spike occurs when the firms' investment rate in this year exceeds the 2 and 2.5 times median value of firms' own investment rate, respectively. In columns (3) and (4), an investment spike occurs when the firms' investment rate in this year exceeds the 2 and 2.5 times median value of industry's investment rate, respectively. We find that the coefficients on LS are negatively and statistically significant. ${ }^{15}$ For example, in column (1), we find that a one-standard-deviation increases in LS results in $20.47 \%$ decrease in the hazard rate of large investment. Overall, these results are supportive for our main hypothesis that lending supply has discipline effect.

\footnotetext{
${ }^{14} \mathrm{LS}$ measure has a quite low first lag autocorrelation of $11.76 \%$, which suggests that we use LS as a time-varying convariate is credible.

${ }^{15}$ The coefficients reported in this table is in the exponential form. Besides, we also include the estimation of baseline hazard. However, since we focus on the coefficients on the covariate of LS, the results of the baseline hazard rates are omitted.
} 


\subsection{Abnormal Capital Investment}

Following Titman et al. (2004), we first calculate the abnormal capital investment $\left(C I_{t}\right)$ in a given year,

$$
C I_{t}=\frac{C E_{t}}{\left(C E_{t-1}+C E_{t-2}+C E_{t-3}\right) / 3}-1
$$

where $t$ represents the year when the abnormal capital investment is calculated, and $C E_{t}$ is a firm capital expenditure (Compustat Data Item 128, CAPEX) scaled by its total asset in year t. We then investigate the effect of short selling on abnormal capital investment, by performing the following regression:

$$
C I_{i, t}=a_{i}+a_{t}+a_{1} \times L S_{i, t-1}+a_{2} \times X_{i, t-1}+\epsilon_{i, t}
$$

where $a_{i}, a_{t}$ are dummies for firm and year fixed effects, respectively. $C I_{i, t}$ is calculated according to Eq.(2). The variable of interest is the coefficient on the LS $\left(a_{1}\right) . X_{i, t-1}$ denotes a set of control variables, including total asset (TotAsset), the logarithm of book to market ratio (BM), fixed asset (FixAsset), firm's age (Age), leverage ratio (Leverage), cash flow (CashFlow), ROA, institutional investor ownership ratio (IOR), the Entrenchment Index proposed in Bebchuk, Cohen, and Ferrell (2009) (E-Index), and Gompers et al. (2003) G-Index. In addition, we cluster the standard error at the firm level.

Table 3 shows the summary statistics for these variables. The mean value of LS is 0.11 with a standard deviation of 0.14 , and the mean value of CI is 0.06 with a standard deviation of 0.80 . The estimation results of Eq.(3) are included in Table 4. The coefficients on LS are negatively significant across all specifications, suggesting that the discipline effect of lending supply on the subsequent abnormal capital investments is significant and robust. It is noteworthy that the results remain qualitatively unchanged when we add E-Index and G-Index in the regression, though the 
sample size decreases dramatically. The discipline force from the short sellers is distinct from the known internal governance mechanism. This effect is economically significant as well. For example, in specification (10), we find that a one-standard-deviation higher in LS leads to $4.38 \%$ standard deviation decrease in the subsequent abnormal capital investment $((0.14 \times(-0.25)) / 0.80=4.38 \%) .{ }^{16}$

The results of other control variables are also worthy of discussion. The coefficients on BM are negatively significant, suggesting that firms' investment level is positively related with firms' growth opportunities, consistent with Richardson (2006). All of the coefficients on leverage are negative and significant, suggesting that firms with high debt ratio are less likely to experience higher abnormal capital investments, consistent with Titman et al. (2004). The coefficients on sales growth are positive and significant in most specifications, suggesting that managers in firms with good past performance tend to build up empire (Morck, Shleifer, and Vishny (1990)). In addition, the coefficient on G-Index is significantly positive, indicating that firms with poor shareholder governance tend to experience higher abnormal capital investment. The E-Index exhibits the expected sign on the coefficient though insignificant.

Overall, these results are supportive to our main hypothesis, suggesting that lending supply has a discipline effect on subsequent managerial empire building. This effect remains strong and significant after controlling for a set of firm-specific variables that have been shown to might affect corporate investments.

\footnotetext{
${ }^{16}$ We will use the same method to compute the economic magnitude of the effect of lending supply throughout the rest of the paper.
} 


\subsection{Mergers and Acquisitions Returns}

In this section, we examine the discipline effect of short selling on managerial acquisition decisions. In particular, we carry out the following regression model:

$$
C A R(-2,2)_{i, t}=a_{0}+a_{1} \times L S_{i, t-1}+a_{2} \times X_{i, t-1}+\epsilon_{i, t}
$$

where $L S_{i, t-1}$ refers to the measure of lending supply for firm $i$ in year $t-1$. $C A R(-2,2)_{i, t}$ refers to the cumulative abnormal return of merger and acquisition for firm $i$ in year $t$, and is computed as the residuals of market model based on 5-day event window $(-2,2)$, where day 0 is the announcement date. ${ }^{17}$ We first use the daily stock return in the period of $(-210,-11)$ to estimate the market model, with CRSP value-weighted return as market return. Then, we use the coefficients derived from this stage to compute the residuals from the market model during event window $(-2,2) . X_{i, t-1}$ includes a set of acquirer- and deal-specific control variables. In particular, acquirer-specific variables consists of the logarithm of total asset (TotAsset), Tobin's Q, leverage, return on asset, compounded daily excess returns over previous year (PastStockReturn), free cash Flow, and non-cash working capital. Deal-specific variables includes the ratio of deal value and the acquirer's market value of total assets (RelativeDealSize), high-tech dummy variable (High-tech), tender offer dummy variable (TenderOffer), friendly deal attitude dummy variable (FriendlyDeal), cash deal dummy variable (CashDeal). ${ }^{18}$ We also include 2-digit industry dummies and year dummies and cluster the standard errors at both firm and year level (Petersen (2009)).

Table 5 presents the summary statistics for M\&A sample firms. We find that the average CAR(-2,2) is $0.20 \%$ with standard deviation of $7.41 \%$. The mean value of LS is 0.11 with standard

\footnotetext{
${ }^{17}$ The way we compute the cumulative abnormal return is based on Chen et al. (2012).

${ }^{18}$ We follow Chen et al. (2012) to use these control variable.
} 
deviation of 0.12. Table 6 reports the regression results of Eq.(4). Across all specifications, the coefficients on LS are positive and statistically significant. It suggests that firms with higher LS experience better market responses for their M\&A announcements. In particular, column (14) suggests that a one-standard-deviation increase in LS is associated with a $8.13 \%$ standard deviation increase in $\operatorname{CAR}(-2,2)$. This set of results implies that when managers face a higher level of potential short selling, they are less likely to conduct value-destroying M\&As for private benefit. Together with the findings in the previous two subsections, our first hypothesis is supported: higher lending supply, i.e., more ammunition for the short sellers, can effectively deter managers from building up empire.

\subsection{Subsequent Firm Value}

In this section, we test our second hypothesis that lending supply has a positive impact on firm value in terms of Tobin's Q. Our previous results demonstrate that high LS would deter managers from undertaking value-destroying investments, which would reduce the agency costs otherwise incurred. We therefore argue that firms with higher LS would experience higher subsequent firm value. Specifically, we perform the regression as follows:

$$
\text { IndAdj_Tobin's } Q_{i, t}=a_{i}+a_{t}+a_{1} \times L S_{i, t-1}+a_{2} \times X_{i, t-1}+\epsilon_{i, t}
$$

where $a_{i}, a_{t}$ are dummies for firm and year fixed effects, respectively. $L S_{i, t-1}$ refers to the measure of lending supply for firm $i$ in year $t$-1. Following Gompers et al. (2003), we employ the industryadjusted Tobin's Q to measure the firm value. In particular, IndAdj_Tobin's $Q$ refers to the ratio of

market value of assets and the book value of assets, and adjusted for the median of 2-digit industry, in which market value of assets is defined as the difference between the sum of the book value of 
assets and the market value of common stock and the sum of book value of common stock and balance sheet-deferred taxes. ${ }^{19}$ The set of control variable, $X_{i, t-1}$, includes: the logarithm of the market capitalization (SIZE), the leverage ratio (Leverage), cash flow (CashFlow), the ratio of R\&D and total asset $(\mathrm{R} \& \mathrm{D}),{ }^{20}$ the ratio of PP\&E and sales (Fixed Asset), the ratio of capital expenditure to the total assets (Capx), the logarithm of cash (Cash), the logarithm of sales (Sale), the firm's age (AGE), the return of equity (ROE), the institutional investors ownership ratio (IOR), the ratio of dividend and book value of equity (Dividend), the ratio of net income to book value of equity (ROE), and the fraction of shares held by insiders, such as CEO, CFO, COO as well as president, to the total shares outstanding (InsiderOwn). ${ }^{21}$ In addition, we also add E-Index and G-Index as described in Gompers et al. (2003) and Bebchuk et al. (2009). These two papers document that both G-Index and E-Index are related to firm value. Hence, we include these two variables to control for the potential discipline effect stemmed from antitakeover provisions. In all specifications, we also cluster standard errors at the firm level.

Table 7 presents the regression results of Eq.(5). The results show a significantly positive correlation between lending supply (LS) and the subsequent firm value. As for column (12), a one-standard-deviation increase in LS leads to a $3.89 \%$ standard deviation increase in industry adjusted Tobin's Q. Although the sample size decreases radically, the governance effect of LS remains significant after adding E-Index or G-Index as shown in column (13) and (14). It is also noteworthy that most of the coefficients on Capx are significantly negative. It suggests a negative relationship between firm's capital investments and subsequent firm value, consistent with the notion that overinvestment can destroy firm future value.

Overall, these results suggest that firms with higher lending supply would experience higher

\footnotetext{
${ }^{19}$ We also require there are at least 5 firms within a certain industry.

${ }^{20}$ We set Dividend and R\&D as zero when firm does not report the dividend and R\&D data in all of our tests.

${ }^{21}$ The construction of the set of control variables is largely based on Kim and Lu (2011).
} 
firm value in the following year, which is consistent with our second hypothesis.

\section{$5 \quad$ Additional Supporting Evidence}

In this section, we conduct three sets of analyses to attribute the documented negative association between the supply of loanable shares and the subsequent empire building to the discipline effect of short selling on managerial decisions. We split our sample into subsamples based on the scaled managerial wealth-performance sensitivity, the firms' financial constraint levels, and the payment method for acquisition. Then we re-estimate our basic regressions to further corroborate our interpretation.

\subsection{Wealth Performance Sensitivity}

In this subsection, we examine whether the sensitivity of managers' wealth to stock price would influence the disciplinary effect of lending supply. The rationale is as follows: if it is the downward price pressure induced by short selling that deters managers from engaging in empire building, the efficiency of this mechanism would substantially hinge on the extent to which managers' wealth is linked to stock price. We use the scaled wealth-performance sensitivity (ScaledWPS), introduced in Edmans et al. (2009), to measure the sensitivity of managers' wealth to stock price. ${ }^{22}$ We expect the disciplinary effect of short selling to be more pronounced for firms with high ScaledWPS level. To test this hypothesis, we partition the whole sample into three groups equally based on ScaledWPS level, and re-estimate our basic regressions in Tables 2, 4, 6, and 7.

The subsample results of the hazard model estimation are presented in columns (1) and (2) of Table 8. In the high ScaledWPS subsample, the coefficient on LS is -1.48 with t-value of 3.24,

\footnotetext{
${ }^{22}$ ScaledWPS represents the dollar change in CEO wealth for a one hundred percentage change in firm value, scaled by annual flow compensation.
} 
while the coefficient on LS in the low ScaledWPS subsample is insignificant though with the right sign. These results suggest that the negatively significant effect of lending supply on hazard rate of over-investment is largely driven by the subsample with higher ScaledWPS.

Likewise, first three columns of Table 9 show that the effect of lending supply on subsequent managerial empire building is negatively significant for firms whose managers' compensation more closely linked to stock price (top tercile ScaledWPS of the sample). Meanwhile, the effect is insignificant for firms with lower ScaledWP, indicating that the significant disciplinary effect of short selling is mainly driven by the firms with higher ScaledWPS.

In addition, we find the negative association between the lending supply and the acquirer firms' announcement returns appears to be only significant in the subsample of firms with higher ScaledWPS. We display the results in columns (1), (2), and (3) of Table 10. It suggests that when managers' wealth is more closely linked to stock price, the discipline mechanism of lending supply is more effective in terms of deterring managers from conducting value-destroying acquisitions.

Finally, we focus on the analysis of the effect of lending supply on the following firms' value. Column (1) of Table 11 displays the results of the whole sample with ScaledWPS data, and columns (2) and (3) include the results of the sample with ScaledWPS in the top and bottom tercile, respectively. We find that the coefficient on the LS in the top tercile is 0.55 with $10 \%$ significance level, which is above 3 times of the value of whole sample. ${ }^{23}$ Meanwhile, the coefficient on the subsample with ScaledWPS in the bottom tercile is insignificant, providing supportive evidence that the discipline effect of LS on managerial empire building is more pronounced when firms' ScaledWPS is high. It is also noteworthy that the coefficients on insider ownership (InsiderOwn) and the square of insider ownership (InsiderOwn ${ }^{2}$ ) indicate a strong and significant hump relationship between

\footnotetext{
${ }^{23}$ A lower significance level in this test might be due to a sufficient decrease in sample size by merging with the ScaledWPS dataset.
} 
firm value and insider ownership, which is consistent with Kim and Lu (2011).

Overall, these results confirm our expectation that the governance effect of short selling is largely driven by the firms with higher sensitivity of managers' wealth to stock price.

\subsection{Financial Constraint}

In this section, we examine how financial constraints affect the disciplinary effect of lending supply. It is intuitive that managers at non-financially-constrained firms are more likely to engage in empire building, since they have more resources to exploit. Therefore, we expect the disciplinary effect of lending supply on managerial empire building would be stronger for these firms that are more vulnerable to this agency problem. In particular, we employ the HP Index, introduced in Hadlock and Pierce (2010), to gauge the extent to which the firm is financially constrained. ${ }^{24}$ We compute the HP index as follows:

$$
H P_{i, t}=-0.727 \times S i z e_{i, t}-0.043 \times S i z e_{i, t}^{2}-0.040 \times A g e_{i, t}
$$

where Size equals to the logarithm of the total assets, and Age is the number of years since the first date of the companys total assets data showed in COMPUSTAT. Following the literature, we winsor Size at the (log of) $\$ 4.5$ billion, and winsor Age at thirty-five year. The higher the HP Index is, the more financially constrained the firm is, as young and small firms are more likely to be financially constrained.

In the hazard model estimation, we divide our sample into three subsamples based on their HP index level, and test whether the hazard rate is higher in firms with low HP index. Columns

\footnotetext{
${ }^{24}$ Hadlock and Pierce (2010) find that firm size and age are useful predictors of the levels of firms' financial constraint. Based solely on firm size and age, they propose a measure of financial constraint (HP Index).
} 
(3) and (4) in Table 8 present the results. For the low HP subsample, the coefficient on LS is -0.75 with t-value of 1.79, while the coefficient on LS in the high HP subsample is insignificant though with the right sign. This suggests that firms with less financial constraint (low HP group) would be more likely to experience shorter duration of two investment spikes, an indicator of empire building.

Likewise, in the tests of abnormal capital investment, we divide our sample into three subsamples conditional on the levels HP Index, and re-estimate the specification of column (9) of Table 4. We display the results in columns (4), (5), and (6) of Table 9. Focusing on the result in column (6), which includes firms with HP Index in the top tercile, the coefficient on LS is -0.31 with $1 \%$ significance level, which is almost two times as much as that in column (4) (whole sample with HP index data). This confirms our hypothesis that the negative association between the lending supply and the subsequent abnormal capital investment is largely driven by firms with less financial constraints.

Moreover, columns (4), (5), and (6) of Table 11 present that the coefficient on LS is 0.32 with $1 \%$ significance level for the subgroup with HP index in the bottom tercile of sample (less financially constrained). However, the effect of LS on the subsequent firm value is insignificant for firms with HP Index in the top tercile of the sample. Overall, these findings provide us additional support for our hypothesis and reinforce the discipline interpretation of our results.

\subsection{Payment method of acquisition}

Fu et al. (2013) find that stock prices of stock-financed bidders are more over-valued than those of cash-financed bidders, and cash-financed deals do not generate average negative cumulative abnormal returns during the announcement period. These results are consistent with the argument in Jensen (2005) that value-destroying acquisition driven by over-valued stock price might reflect the 
agency costs associated with stock overvaluation. In this subsection, we therefore divide mergers and acquisitions sample into two subsamples based on whether the deal is $100 \%$ cash-financed. We expect that the discipline effect of LS plays a less important role when acquirers use all cash method to pay, as less agency costs are associated with cash-financed acquisition. Columns (4), (5) and (6) in Table 10 present the results. In column (6), we only include acquisitions using all cash payment method, and column (5) refers to the rest of the deals that use at least some stocks as payment method. Indeed, we find that the positive association between LS and CAR(-2,2) only exists in non-all-cash deals. In particular, a one-standard-deviation increase in LS results in an increase of $21.19 \%$ standard deviation of 5-day abnormal stock announcement returns of acquirer firms, which is almost three times as much as that of in column (4) (the whole sample). It suggests that the discipline effect of lending supply is more prominent in stock-financed acquisitions through which managers are more likely to take advantage of overvalued stocks to build up empire.

\section{Endogeneity Issue}

\subsection{Pilot Program}

In order to tackle the potential endogeneity issue, we employ a regulation change in U.S. equity market, Regulation SHO (2005-2007), which eliminates the the price restriction of short selling for a set of randomly selected firms. Regulation SHO is announced by SEC in 2004, which randomly selects around 1,000 pilot firms and removes their price restrictions (uptick rules) for short selling from January, 3, 2005 to August 6, 2007. ${ }^{25}$ We argue that the lift of price restriction for short selling enhances the governance effect of lending supply on managerial empire building behavior, since lower short sale constraint poses a greater threat to the managers. In particular, we perform

\footnotetext{
${ }^{25}$ For the details of the program, see also Diether, Lee, and Werner (2009).
} 
the following regression models:

$$
\begin{aligned}
& C I_{i, t}=a_{i}+a_{t}+a_{1} \times L S_{i, t-1}+a_{2} \times L S_{i, t-1} \times \text { Treated } \times \text { Pilot }+a_{3} \times L S_{i, t-1} \times \text { Treated }+ \\
& a_{4} \times L S_{i, t-1} \times \text { Pilot }+a_{5} \times \text { Treated } \times \text { Pilot }+a_{6} \times \text { Pilot }+a_{7} \times X_{i, t-1}+\epsilon_{i, t} \\
& (\text { IndAdj_Tobin's } Q)_{i, t}=a_{i}+a_{t}+a_{1} \times L S_{i, t-1}+a_{2} \times L S_{i, t-1} \times \text { Treated } \times \text { Pilot }+ \\
& a_{3} \times L S_{i, t-1} \times \text { Treated }+a_{4} \times L S_{i, t-1} \times \text { Pilot }+a_{5} \times \text { Treated } \times \text { Pilot }+a_{6} \times \text { Pilot }+ \\
& a_{7} \times X_{i, t-1}+\epsilon_{i, t}
\end{aligned}
$$

where $a_{i}, a_{t}$ are dummies for firm and year fixed effects, respectively. $C I_{i, t}$ is calculated according to Eq.(2), and IndAdj_Tobin's $Q_{i, t}$ is computed according to the procedure in Section 4.5. Treated is a dummy variable indicating firms that are selected as Reg SHO pilot stock. Pilot is a time dummy which equals one from 2005 to 2007 , otherwise zero. $X_{i, t-1}$ denotes a set of control variables, which is same to the Section 4.3 and Section 4.5. In this test, our sample is from 2002 till the end of the PILOT program (2007). In addition, we cluster the standard error at the firm level. As we control for the firm fixed effect, the coefficient on the Treated dummy is omitted.

Our main variable of interest is the coefficient on the three-way interaction, $a_{2}$. Table 12 shows that $a_{2}$ is negatively significant in columns (1) and (2), and positively significant in columns (3) and (4), suggesting that the lift of price restriction for short selling enhances the disciplinary effect of LS on the subsequent empire building and then increase firm values. This set of the results assures us that our previous findings are not driven by potential endogeneity or omitted variable issues. 


\subsection{Residual of Lending Supply}

Besides the quasi-natural experiment of PILOT program, we also use the residual LS to validate our arguments. In particular, we estimate the residual term of LS regressing on firm size, book-tomarket ratio, firm age, institutional ownership ratio, and turnover ratio with controlling for firm and year fixed effects. ${ }^{26}$ Since our measure of residual LS is by construction orthogonal to these firm characteristics, we argue that our previous findings do not merely reflect the effects of the firm characteristics that are known to be associated with investments and firm values.

We re-estimate our major regression models by using residual LS, and we present the results in Table 13. In column (1), we find that the negative relation between LS and the subsequent CI still holds when we use the residual LS measure. In column (2), we find that the coefficient on the residual LS is 0.049 at $5 \%$ significance level, suggesting the discipline effect of lending supply on the managerial value-destroying mergers and acquisitions are robust to using residual LS. In column (3), we find a positive and significant relation between residual LS and the subsequent firm value. Overall, these results suggest that our main findings are robust and supportive to our hypothesis that lending supply has discipline effect on managerial empire building.

\footnotetext{
${ }^{26}$ Literature has shown that institutional ownership and equity returns is related, we therefore add IOR to ensure that our results are not driven by the effects from institutional investors (Gompers and Metrick (2001); Yan and Zhang (2009)).
} 


\section{Conclusion}

In this paper, we examine the disciplinary effect of lending supply in the short selling market on deterring managers from empire building. Employing the lending supply data from 2002 to 2011, we find that firms with more lending supply will have low hazard rate and long spells between two adjacent investment spikes. We also find that firms with more lending supply are less likely to experience abnormal capital investment in the subsequent year. Besides, we document a positive association between the lending supply and the mergers and acquisitions announcement returns of acquiring firms, suggesting that a higher level of lending supply would also deter managers from conducting value-destroying acquisitions. In addition, we document a positive relation between lending supply and subsequent firm value. The firm value improves because the effective threat of short selling discourages managers from value-destroying empire building.

Importantly, we find that the discipline effect is more prominent for firms with high managers' wealth-performance sensitivity (ScaledWPS) but insignificant for firms with low ScaledWPS. As the effectiveness of the lending supply largely hinges on the sensitivity of managers' wealth to stock price, this result helps to attribute our findings to the discipline effect of short selling on managerial misbehavior. In addition, we also find the discipline effect is stronger for firms with less financial constraints and for stock-financed M\&A deals. These results indicate that managers tend to build up empires in less financially constrained firms and in stock-financed acquisition deals, in which the discipline effect of lending supply on managerial behavior would manifest. We also find that the association between lending supply and subsequent firm value is stronger for firms with high ScaledWPS and less financial constraints.

To mitigate the endogeneity concerns, we employ the Regulation SHO, which eliminates the 
price restriction of short selling for a set of randomly selected firms. The multivariate differencein-difference results indicate that the lending supply has stronger discipline effect for firms that are exempted from the short selling price restriction. This result provides coherent evidence that short selling takes role in corporate governance, and its discipline force is more effective when short selling is less restricted. Finally we employ the residual LS regressing on firm size, book-to-market ratio, firm age, institutional ownership ratio, and turnover ratio, as an alternative measure of short selling discipline force, and find our main results still hold. It indicates that our main findings are robust to controlling for those firm characteristics and supportive to our hypothesis that lending supply has discipline effect on managerial empire building. 


\section{Appendix A: Hazard Model Estimation for Empire Building}

This appendix describes the methodology for estimating the hazard model of empire building. We adopt and follow the approach of Whited (2006). Specifically, following Meyer (1990), Whited (2006) uses nonparametric specification, including unobservable heterogeneity and time-varying explanatory variable, and defines the proportional hazard form as:

$$
\lambda_{i}(t)=\omega_{i} \lambda_{0}(t) \exp \left(x_{i}(t)^{\prime} \beta\right)
$$

A hazard model contains two parts. The first part, denoted as $\lambda_{0}(t)$, is the baseline hazard function, which is a function of time duration. The second part is $\exp \left(x_{i}(t)^{\prime} \beta\right)$, which represents a function of explanatory variables. $x_{i}(t)$ represents a vector of covariates which identifies observable differences across individual firms. $\beta$ is the vector of coefficients of those covariates, which allows the hazard rates moves upward or downward according to different value of covariates. $t$ represents the length of a spell, the duration between two investment spikes. $\omega_{i}$ is a random variable and represents the unobservable heterogeneity, it is assumed to follow Gamma distribution and with unit mean and variance, $\sigma^{2} \cdot{ }^{27}$

Maximum likelihood method is employed to estimate the coefficients. Denote $T_{i}$ as the actual length of time between investment spikes and the censoring time as $C_{i}$ for firm i. Define $\delta_{i}=1$ if $T_{i} \leq C_{i}$ and 0 otherwise. Let $h_{i}=\min \left(T_{i}, C_{i}\right)$. The Log-likelihood function is as follows:

$$
L(\gamma, \beta)=\sum_{i=1}^{N} \ln \left\{\left[1+\sigma^{2} \sum_{t=0}^{h_{i}-1} \exp \left(x_{i}(t)^{\prime} \beta+\gamma(t)\right)\right]^{-1 / \sigma^{2}}-\delta_{i}\left[1+\sigma^{2} \sum_{t=0}^{h_{i}} \exp \left(x_{i}(t)^{\prime} \beta+\gamma(t)\right)\right]^{-\left(1 / \sigma^{2}\right)}\right.
$$

where

$$
\gamma(t)=\ln \left(\int_{t}^{t+1} \lambda_{0}(s) d s\right)
$$

and $\sigma$ represents the variance of the gamma distribution. The estimation method would select the shape of the hazard to maximize the likelihood of observed durations in the sample.

\footnotetext{
${ }^{27}$ The hazard model method also allows for right-censoring of data. For example, if a firm experience an investment spike in 2003, and the firm's data ended in 2006, then the length of the firm's final spell would be censored to three years.
} 


\section{Appendix B: Variable Definitions}

\begin{tabular}{|c|c|}
\hline Lending Supply (LS) & The ratio of the value of shares available supplied for lending and firm's market capitalization \\
\hline CI & $\begin{array}{l}\text { Following Titman, Wei and Xie (2004), we construct the measure of abnormal capital in- } \\
\text { vestment as the ratio of CPAX/Total Asset. }\end{array}$ \\
\hline IndAdj_Tobin's $Q$ & $\begin{array}{l}\text { The ratio of market value of assets and the book value of assets, and adjusted for the median } \\
\text { of 2-digit industry, in which market value of assets is defined as the difference between the } \\
\text { sum of the book value of assets and the market value of common stock and the sum of book } \\
\text { value of common stock and balance sheet-deferred taxes. }\end{array}$ \\
\hline IOR & The ratio of the institutional investors ownership to the total shares outstanding. \\
\hline TotAsset & The logarithm of total assets. (item 6 from COMPUSTAT) \\
\hline Leverage & The ratio of the long term debt $(\mathrm{dltt}+\mathrm{dls})$ to the total assets. \\
\hline $\mathrm{ROA}$ & The ratio of net income to the total assets. \\
\hline Tobin's Q & $\begin{array}{l}\text { The ratio of market value of assets and the book value of assets. (Market value of assets is } \\
\text { defined as the difference between the sum of the book value of assets and the market value } \\
\text { of common stock and the sum of book value of common stock and balance sheet-deferred } \\
\text { taxes.) }\end{array}$ \\
\hline $\mathrm{BM}$ & The logarithm of the ratio of the book value of equity divided by the market value of equity. \\
\hline SaleGrowth & Changes in sales scaled by lagged sales. \\
\hline CashFlow & $\begin{array}{l}\text { The sum of income before extraordinary items and depreciation and amortization, scaled by } \\
\text { total assets. }\end{array}$ \\
\hline $\mathrm{R} \& \mathrm{D}$ & The ratio of $\mathrm{R} \& \mathrm{D}$ and the total assets. \\
\hline FixedAsset & The ratio of PP\&E to the sales. \\
\hline Dividend & The ratio of the dividend to the book value of equity. \\
\hline Sale & The logarithm of the sales. \\
\hline AGE & The first date of the company total assets data in COMPUSTAT (in logarithm). \\
\hline Capx & The ratio of capital expenditure to the total assets. \\
\hline Cash & The logarithm of the cash. \\
\hline HP Index & Computed based on the methodology described in Hadlock and Pierce (2010). \\
\hline ScaledWPS & $\begin{array}{l}\text { Following Edmans, Gabaix, and Landier (2009), we employ scaled wealth-performance sen- } \\
\text { sitivity to capture the sensitivity of the manager's wealth to the stock price. It is the dollar } \\
\text { change in the CEOs wealth for a } 100 \text { percentage point change in the stock price, scaled by } \\
\text { annual pay. }\end{array}$ \\
\hline E_index & The Entrenchment index of Bebchuck, Cohen and Ferrell (2009). \\
\hline G_Index & The governance index of Gompers, Ishii and Metrick (2003). \\
\hline Insider Ownership & $\begin{array}{l}\text { The fraction of shares held by insiders (CEO, CFO, COO, President) to the total shares } \\
\text { outstanding. }\end{array}$ \\
\hline PastStockReturns & Compounded daily stock returns over previous year of the merger and acquisition (log). \\
\hline High-tech & $\begin{array}{l}\text { A dummy variable equals to one when both acquirer and target are from the high-tech } \\
\text { industries (from SDC), zero otherwise. }\end{array}$ \\
\hline RelativeDealSize & The ratio of the deal value (from SDC) and the firm's market value of total assets. \\
\hline TenderOffer & A dummy variable equals to one when the deal involves a tender offer, zero otherwise. \\
\hline FriendlyDeal & A dummy variable equals to one when the deal attitude is friendly, zero otherwise. \\
\hline FreeCashFlow & $\begin{array}{l}\text { The difference between operating income before depreciation and the summation of the } \\
\text { interest expense, income taxes, and capital expenditure, scaled by total asset. }\end{array}$ \\
\hline NonCashWorking & $\begin{array}{l}\text { The difference between the current assets and the summation of the current liabilities and } \\
\text { cash and cash equivalents, scaled by total assets. ROA is the ratio of net income to total } \\
\text { assets. }\end{array}$ \\
\hline CashDeal & A dummy variable equals to one when the pay method is $100 \%$ cash. \\
\hline
\end{tabular}


Table 1. Summary Statistics: Analysis for hazard model

This table reports the descriptive statistics for sample firms in hazard model test. Investment/Asset is the calculated as (data30-data107)/data6. CashFlow is the sum of income before extraordinary items and depreciation and amortization, scaled by total assets. SaleGrowth is the growth rate of sales. TotAsset is the logarithm of data6. Lending Supply (LS) is the ratio of the value of shares available supplied for lending and firm's market capitalization. Leverage is the (data9+data34)/data6. A firm is included if its real assets are below the 33rd percentile of the real assets of the firms in the first year that the firm appears in the our sample. Avg. spell length measures the average number of years that the firm's investment rate does not go beyond the pre-defined investment threshold. We employ 2 times of the firm's median investment rate as the investment trigger. Fraction censored refers to the percentage of right censored spells in the sample. Length censored (uncensored) refers to the number of censored (uncensored) years that a firm remains inactive.

\begin{tabular}{|c|c|c|c|c|}
\hline & $\mathrm{N}$ & Mean & Median & Std. Dev \\
\hline \multicolumn{5}{|c|}{ Panel A: Firm Characteristics } \\
\hline Investment/Asset & 4319 & 0.0388 & 0.0200 & 0.0666 \\
\hline LS & 4506 & 0.0602 & 0.0415 & 0.0624 \\
\hline Leverage & 4505 & 0.1045 & 0.0542 & 0.1284 \\
\hline CashFlow & 4507 & -0.0472 & 0.0422 & 0.2626 \\
\hline SalesGrowth & 4498 & 0.2764 & 0.1214 & 0.7070 \\
\hline TotAsset & 4507 & 3.7855 & 3.8964 & 1.0073 \\
\hline \multicolumn{5}{|c|}{ Panel B: Spell Characteristics } \\
\hline Avg. spell length & 1219 & 3.4807 & 3.0000 & 2.2210 \\
\hline Fraction censored & 1219 & 0.5193 & 0 & 0 \\
\hline Length censored & 633 & 4.6951 & 4.0000 & 2.1781 \\
\hline Length uncensored & 586 & 2.6177 & 2.0000 & 1.8297 \\
\hline
\end{tabular}


Table 2. Semi-parametric hazard model estimates: effects of Lending Supply (LS)

LS is the ratio of the value of shares available supplied for lending and firm's market capitalization, which covers from 2002 to 2011. Following Whited (2006) and Billet et al. (2011), we include firms whose real assets are below the 33rd percentile of the real assets in the first year that the firm appears in sample. CashFlow is the sum of net income and depreciation divided by total assets. Sales growth is the growth rate of sales. A spike is defined as an investment rate exceeds a threshold, and the thresholds are pre-defined as 2 and 2.5 times the firm median investment rate (or firms' industry's median contemporaneous investment rate). The number of year since the last spike has also been included, though coefficients are omitted. $t$-values are in parentheses. ${ }^{* * *}$, and $* * *$ indicate statistical significance at the $10 \%, 5 \%$, and $1 \%$ level, respectively.

\begin{tabular}{rrrrr}
\hline \hline & \multicolumn{1}{c}{ Firm } & & \multicolumn{2}{c}{ Industry } \\
& $(1) 2$ times & $(2) 2.5$ times & $(3) 2$ times & $(4) 2.5$ times \\
\hline LS & -0.6855 & -0.7959 & -0.2290 & -0.2006 \\
& $(7.93)^{* * *}$ & $(7.18)^{* * *}$ & $(4.28)^{* * *}$ & $(4.45)^{* * *}$ \\
Leverage & -1.5821 & -1.7582 & 0.4493 & 0.1618 \\
& $(3.69)^{* * *}$ & $(3.45)^{* * *}$ & $(1.28)$ & $(0.52)$ \\
SalesGrowth & 0.1802 & 0.1558 & 0.0526 & 0.0344 \\
& $(3.34)^{* * *}$ & $(3.70)^{* * *}$ & $(1.05)$ & $(0.71)$ \\
CashFlow & -0.2329 & -0.2247 & 1.2772 & 1.0472 \\
& $(1.25)$ & $(1.08)$ & $(5.90)^{* * *}$ & $(5.74)^{* * *}$ \\
TotAsset & 0.0022 & -0.1037 & 0.0174 & 0.0383 \\
& $(0.04)$ & $(1.57)$ & $(0.34)$ & $(0.84)$ \\
obs & 4495 & 4498 & 4498 & 4494 \\
Year Dummy & Yes & Yes & Yes & Yes \\
Ind. Dummy & Yes & Yes & Yes & Yes \\
log likelihood & -1575.49 & -1240.28 & -2104.28 & -1782.66 \\
\hline
\end{tabular}


Table 3. Summary Statistics: Analysis for abnormal capital investments and firms value

Lending Supply (LS) is the ratio of the value of shares available supplied for lending and firm's market capitalization. Leverage is the ratio of long term debt to total assets. CashFlow is the sum of income before extraordinary items and depreciation and amortization, scaled by total assets. SalesGrowth refers to the changes in sales scaled by lagged sales. TotAsset is the logarithm of total asset. BM is the logarithm of the book-to-market ratio. Firm value is calculated as the Tobin's Q, the ratio of book value of assets minus book value of equity plus market value of equity to the book value of total assets. ROA is the ratio of net income to total assets. Age is derived from the first date of the companies total assets data in Compustat (logarithm). Capx is the ratio of capital expenditure to the total assets. IOR is the ratio of the institutional ownership to the total shares outstanding. IndAdj_Tobin's $Q$ is referred to the ratio of market value of assets and the book value of assets, and adjusted for the median of 2-digit industry, in which market value of assets is defined as the difference between the sum of the book value of assets and the market value of common stock and the sum of book value of common stock and balance sheet-deferred taxes. Sale is logarithm of the sale. Dividend is the ratio of dividend and book value of equity. ROE is the ratio of net income to book value of equity. R\&D is the ratio of $R \& D$ and total asset. FixedAsset is the ratio of PP\&E and total sales. Following Edmans et al. (2009), we employ scaled wealth-performance sensitivity to capture the sensitivity of the manager's wealth to the stock price (ScaledWPS). This measure is the dollar change in the CEOs wealth for a 100 percentage point change in the stock price, scaled by annual pay. InsiderOwn is equal to the fraction of shares held by insiders, such as CEO, CFO, $\mathrm{CO}$ as well as president, to the total shares outstanding. E_Index is the Entrenchment index of Bebchuk et al. (2009). G_Index is the governance index of Gompers et al. (2003). The detailed definitions of these variables are reported in Appendix B.

\begin{tabular}{|c|c|c|c|c|}
\hline Variables & $\mathrm{N}$ & Mean & Median & Std. Dev \\
\hline CI & 24291 & 0.0565 & -0.1010 & 0.7997 \\
\hline $\mathrm{LS}$ & 24930 & 0.1110 & 0.0648 & 0.1420 \\
\hline IOR & 24995 & 0.5768 & 0.6255 & 0.3016 \\
\hline TotalAsset & 24995 & 6.2558 & 6.1942 & 2.0235 \\
\hline $\mathrm{BM}$ & 24925 & -0.7856 & -0.7089 & 0.8617 \\
\hline CashFlow & 24959 & 0.0239 & 0.0722 & 0.2149 \\
\hline Tobin's Q & 24991 & 1.9447 & 1.4990 & 1.3299 \\
\hline $\mathrm{ROA}$ & 24995 & -0.0166 & 0.0360 & 0.2184 \\
\hline SalesGrowth & 24702 & 0.1560 & 0.0839 & 0.4473 \\
\hline Leverage & 24888 & 0.1863 & 0.1428 & 0.1904 \\
\hline HP Index & 23496 & -7.1846 & -6.7695 & 2.9006 \\
\hline ScaledWPS (in thousands) & 11581 & 0.0280 & 0.0065 & 0.0856 \\
\hline MktSize & 23208 & 6.2987 & 6.2717 & 1.9311 \\
\hline IndAdj_Tobin's $Q$ & 23867 & -0.3858 & -0.4563 & 1.3419 \\
\hline Sale & 23682 & 6.0795 & 6.1532 & 2.1099 \\
\hline $\mathrm{AGE}$ & 23825 & 2.6486 & 2.6391 & 0.8769 \\
\hline DIV & 23657 & 0.0227 & 0.0000 & 0.0564 \\
\hline $\mathrm{R} \& \mathrm{D}$ & 23686 & 0.0043 & 0.0000 & 0.0284 \\
\hline PPE & 23672 & 0.8672 & 0.3750 & 1.5271 \\
\hline CAPX & 23835 & 0.0479 & 0.0299 & 0.0559 \\
\hline Cash & 23868 & 0.3734 & 0.0596 & 1.1243 \\
\hline InsideOwnership & 23862 & 0.0629 & 0.0178 & 0.1106 \\
\hline $\mathrm{ROE}$ & 23870 & 0.0376 & 0.0880 & 0.3955 \\
\hline E_Index & 7565 & 2.4726 & 3.0000 & 1.2505 \\
\hline G_Index & 7678 & 9.0619 & 9.0000 & 2.6278 \\
\hline
\end{tabular}


Table 4. Lending Supply and the Subsequent Abnormal Capital Investment

This table reports the regression results for Eq.(3). The dependent variable is abnormal capital investment (Titman et al. (2004)). LS is the ratio of the value of shares available supplied for lending and firm's market capitalization, which covers from 2002 to 2011. IOR is the ratio of the institutional ownership to the total shares outstanding. TotAsset is the logarithm of total asset. BM is the logarithm of the book-to-market ratio. CashFlow is the sum of income before extraordinary items and depreciation and amortization, scaled by total assets. ROA is the ratio of net income to total assets. SaleGrowth is the changes in sales scaled by lagged sales. Leverage is the ratio of long term debt to total assets. E_Index is the Entrenchment index of Bebchuk et al. (2009). G_ Index is the governance index of Gompers et al. (2003). All regressions control for year and firm fixed effects, whose coefficient estimates are suppressed. Heteroskedasticity-consistent standard errors clustered at the firm level. $t$-values are in parentheses. $*$,**, and *** indicate statistical significance at the $10 \%, 5 \%$, and $1 \%$ level, respectively.

\begin{tabular}{|c|c|c|c|c|c|c|c|c|c|c|c|}
\hline \multicolumn{12}{|c|}{ Subsequent Abnormal Capital Investment } \\
\hline & $(1)$ & $(2)$ & (3) & (4) & (5) & $(6)$ & $(7)$ & $(8)$ & (9) & $(10)$ & (11) \\
\hline \multirow{2}{*}{ LS } & -0.2130 & -0.2608 & -0.3004 & -0.1670 & -0.1550 & -0.1710 & -0.1729 & -0.1796 & -0.1320 & -0.2521 & -0.2147 \\
\hline & $(3.52)^{* * *}$ & $(4.31)^{* * *}$ & $(4.94)^{* * *}$ & $(2.60)^{* * *}$ & $(2.41)^{* *}$ & $(2.66)^{* * *}$ & $(2.68)^{* * *}$ & $(2.77)^{* * *}$ & $(2.02)^{* *}$ & $(2.50)^{* *}$ & $(2.30)^{* *}$ \\
\hline \multirow[t]{2}{*}{ IOR } & & 0.2211 & 0.3597 & 0.3225 & 0.2750 & 0.2855 & 0.2915 & 0.3167 & 0.2686 & 0.3139 & 0.2115 \\
\hline & & $(3.04)^{* * *}$ & $(4.78)^{* * *}$ & $(4.31)^{* * *}$ & $(3.69)^{* * *}$ & $(3.83)^{* * *}$ & $(3.91)^{* * *}$ & $(4.32)^{* * *}$ & $(3.65)^{* * *}$ & $(2.36)^{* *}$ & $(1.69)^{*}$ \\
\hline \multirow[t]{2}{*}{ TotAsset } & & & -0.1600 & -0.1556 & -0.1153 & -0.1019 & -0.1116 & -0.1325 & -0.1031 & -0.2205 & -0.2353 \\
\hline & & & $(5.84)^{* * *}$ & $(5.64)^{* * *}$ & $(4.22)^{* * *}$ & $(3.65)^{* * *}$ & $(3.94)^{* * *}$ & $(4.86)^{* * *}$ & $(3.76)^{* * *}$ & $(5.31) * * *$ & $(5.73)^{* * *}$ \\
\hline \multirow[t]{2}{*}{$\mathrm{BM}$} & & & & -0.0947 & -0.1155 & -0.1045 & -0.1009 & -0.0909 & -0.1050 & -0.1468 & -0.1390 \\
\hline & & & & $(5.68) * * *$ & $(6.63)^{* * *}$ & $(6.01)^{* * *}$ & $(5.80) * * *$ & $(5.25) * * *$ & $(6.03)^{* * *}$ & $(5.43)^{* * *}$ & $(5.09)^{* * *}$ \\
\hline \multirow{2}{*}{ CashFlow } & & & & & -0.3756 & -0.3829 & -1.1153 & -1.0973 & -1.0201 & -0.4408 & -0.1186 \\
\hline & & & & & $(4.57)^{* * *}$ & $(4.66)^{* * *}$ & $(4.09)^{* * *}$ & $(4.03)^{* * *}$ & $(3.82)^{* * *}$ & $(1.15)$ & $(0.26)$ \\
\hline \multirow[t]{2}{*}{ Tobin's Q } & & & & & & 0.0285 & 0.0278 & 0.0288 & 0.0226 & 0.0173 & 0.0143 \\
\hline & & & & & & $(2.30)^{* *}$ & $(2.24)^{* *}$ & $(2.32)^{* *}$ & $(1.82)^{*}$ & $(0.96)$ & $(0.76)$ \\
\hline \multirow[t]{2}{*}{ ROA } & & & & & & & 0.7213 & 0.7241 & 0.5338 & 0.1345 & -0.2662 \\
\hline & & & & & & & $(2.79)^{* * *}$ & $(2.81)^{* * *}$ & $(2.11)^{* *}$ & $(0.40)$ & $(0.62)$ \\
\hline \multirow[t]{2}{*}{ SaleGrowth } & & & & & & & & 0.0783 & 0.0775 & 0.1563 & 0.1664 \\
\hline & & & & & & & & $(3.17)^{* * *}$ & $(3.15)^{* * *}$ & $(3.56)^{* * *}$ & $(3.62)^{* * *}$ \\
\hline \multirow[t]{2}{*}{ Leverage } & & & & & & & & & -0.6532 & -0.4789 & -0.6274 \\
\hline & & & & & & & & & & $(3.21)^{* * *}$ & $(4.08)^{* * *}$ \\
\hline \multirow[t]{2}{*}{ E_Index } & & & & & & & & & & 0.0137 & \\
\hline & & & & & & & & & & $(0.53)$ & \\
\hline G_Index & & & & & & & & & & & $\begin{array}{c}0.0204 \\
(1.20)\end{array}$ \\
\hline Ye & & $\mathrm{Y}$ & Y & Y & Y & $\mathrm{Ye}$ & $\mathrm{Ye}$ & Yes & Yes & Yes & Yes \\
\hline irm Dummies & Yes & Yes & Yes & Yes & Yes & Yes & Yes & Yes & Yes & Yes & Yes \\
\hline No. & 24273 & 24273 & 24273 & 24269 & 24251 & 24250 & 24250 & 24019 & 23916 & 7375 & 7494 \\
\hline$R^{2}$ & 0.2476 & 0.2482 & 0.2512 & 0.2538 & 0.2564 & 0.2569 & 0.2575 & 0.2542 & 0.2584 & 0.3576 & 0.3311 \\
\hline
\end{tabular}


Table 5. Summary Statistics: Analysis for the mergers and acquisitions The sample consists of domestic mergers and acquisition from 2003-2012. CAR(-2,2) is the cumulative abnormal return calculated using a market model estimated over the period $[-210,-11]$ relative to the announcement date (day 0). Lending Supply (LS) is the measure of the value of shares that are available for rent, scaled by firm's market capitalization. TotAsset is logarithm of the item 6 in COMPUSTAT. Compounded daily stock returns over previous year of the merger and acquisition $(\log )$. ROA is the ratio of net income to total assets. Tobin's Q is the ratio of book value of assets minus book value of equity plus market value of equity to the book value of total assets. FixedAsset is the ratio of property, plant, and equipment (PP\&E) and sales. $R \& D$ is the ratio of $R \& D$ and the total asset. RelativeDealSize is the ratio of the deal value (from SDC) and the firm's market value of total assets. Leverage is the ratio of long term debt to total assets. FreeCashFlow is the difference between operating income before depreciation and the summation of the interest expense, income taxes, and capital expenditure, scaled by total asset. The detailed definitions of these variables are reported in Appendix B.

\begin{tabular}{|c|c|c|c|c|}
\hline & $\mathrm{N}$ & Mean & Median & Std. Dev \\
\hline $\mathrm{CAR}(-2,2)$ & 1018 & 0.0020 & 0.0031 & 0.0741 \\
\hline $\mathrm{LS}$ & 1018 & 0.1106 & 0.0714 & 0.1222 \\
\hline TotAsset & 1018 & 6.8782 & 6.8251 & 1.8304 \\
\hline PastStockReturn & 1017 & 0.0905 & 0.1307 & 0.4496 \\
\hline ROA & 1018 & 0.0368 & 0.0533 & 0.1616 \\
\hline Tobin's Q & 1018 & -1.1029 & -0.7570 & 1.3634 \\
\hline FixedAsset & 1018 & 0.2286 & 0.1460 & 0.2197 \\
\hline $\mathrm{R} \& \mathrm{D}$ & 1018 & 0.0416 & 0.0038 & 0.0738 \\
\hline NonCashWorking & 974 & 0.2331 & 0.2102 & 0.2122 \\
\hline Leverage & 1013 & 0.1902 & 0.1566 & 0.1780 \\
\hline FreeCashFlow & 1018 & 0.0294 & 0.0390 & 0.1222 \\
\hline RelativeDealSize & 1018 & 0.1772 & 0.0843 & 0.2389 \\
\hline FriendlyDeal & 1018 & 0.9882 & 1.0000 & 0.1080 \\
\hline High-tech & 1018 & 0.4273 & 0.0000 & 0.4949 \\
\hline TenderOffer & 1018 & 0.0766 & 0.0000 & 0.2661 \\
\hline CashDeal & 1018 & 0.4008 & 0.0000 & 0.4903 \\
\hline IOR & 1018 & 0.6553 & 0.7321 & 0.2773 \\
\hline ScaledWPS & 541 & 61.5683 & 6.6914 & 642.0740 \\
\hline
\end{tabular}




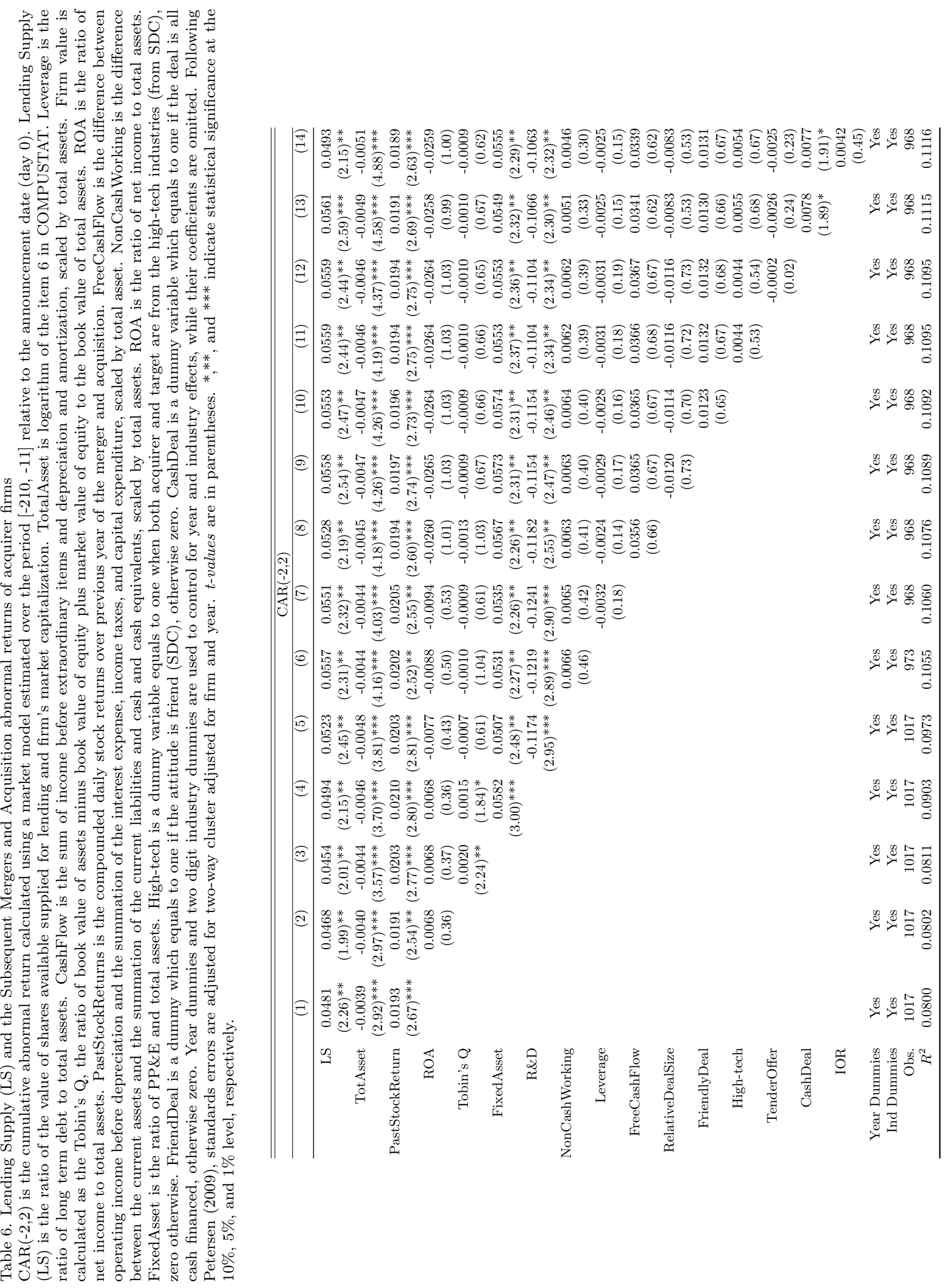




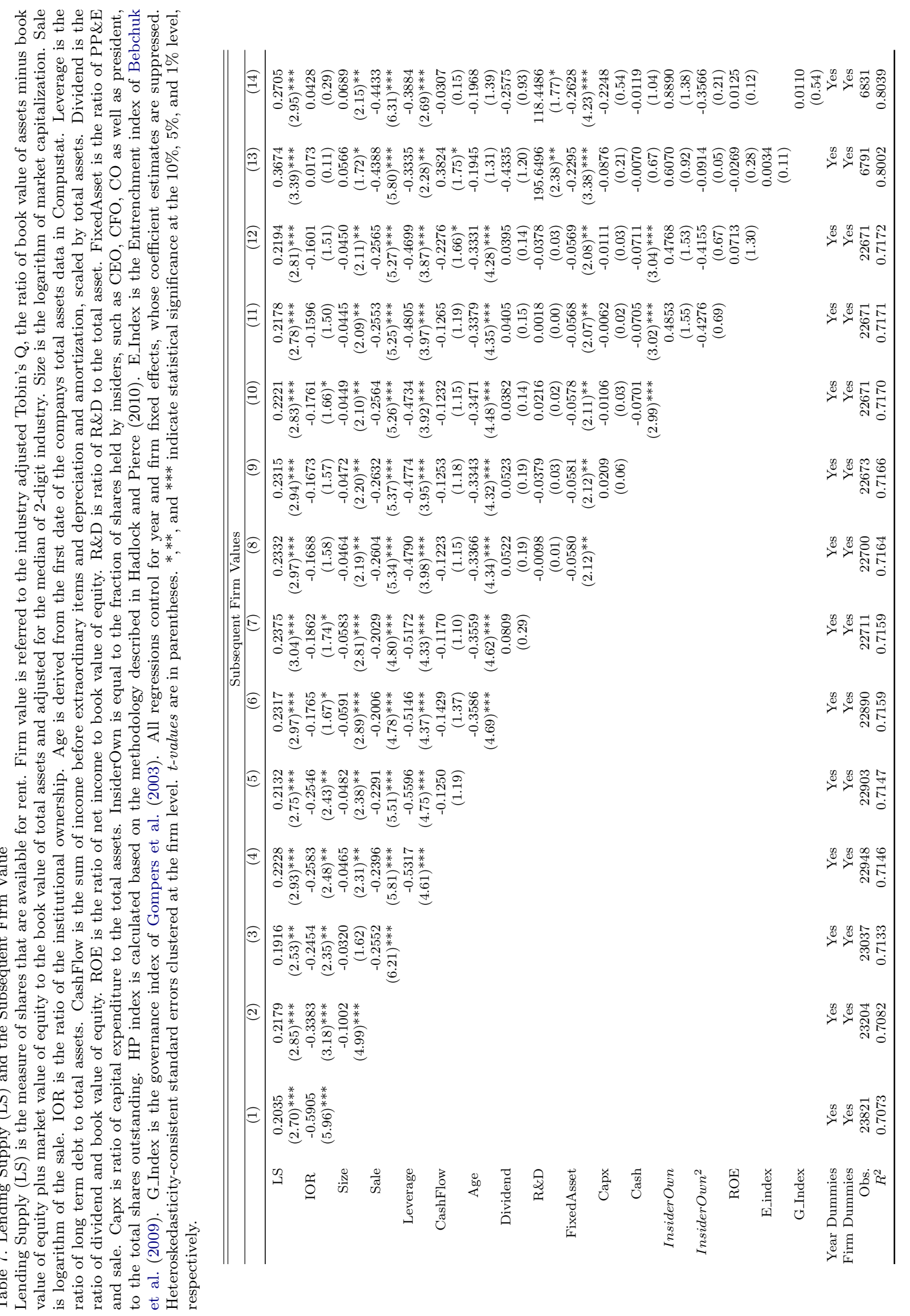


Table 8. Semi-parametric hazard model estimates: the effects of ScaledWPS and HP Index

LS is the ratio of the value of shares available supplied for lending and firm's market capitalization, which covers from 2002 to 2011. Following Whited (2006) and Billet et al. (2011), we include firms whose real assets are below the 33rd percentile of the real assets in the first year that the firm appears in sample. Following Edmans, Gabaix, and Landier (2009), ScaledWPS is the measure of scaled wealth performance sensitivity, the dollar change in wealth for a one-percentage-point change in firm value, divided by annual pay. We construct HP index, by using the methodology described in Hadlock and Pierce (2010). A firm is defined as a high (low) ScaledWPS firm if its average ScaledWPS is above (below) the 67th (33rd) percentile of the average ScaledWPS. A firm is defined as a high (low) HP Index firm if its average HP Index is above (below) the 67th (33rd) percentile of the average HP Index. Cash flow is the sum of net income and depreciation divided by total assets. Sales growth is the growth rate of sales. A spike is defined as an investment rate exceeds a threshold, and the threshold is pre-defined in terms of 2 times the firm median investment rate. The number of year since the last spike has also been included, though coefficients are omitted. $t$-values are in parentheses. ${ }^{*}, * *$, and ${ }^{* * *}$ indicate statistical significance at the $10 \%, 5 \%$, and $1 \%$ level, respectively.

\begin{tabular}{|c|c|c|c|c|}
\hline & \multicolumn{4}{|c|}{ Hazard Estimation } \\
\hline & \multicolumn{2}{|c|}{ ScaledWPS } & \multicolumn{2}{|c|}{ HP Index } \\
\hline & (1) High & (2) Low & (3) High & (4) Low \\
\hline \multirow[t]{2}{*}{$\mathrm{LS}$} & -1.4811 & -0.7517 & -0.1273 & -0.7477 \\
\hline & $(3.24)^{* * *}$ & $(1.08)$ & $(0.33)$ & $(1.79)^{*}$ \\
\hline \multirow[t]{2}{*}{ Leverage } & -3.1972 & -5.2735 & 0.2169 & -5.0601 \\
\hline & (1.19) & $(0.57)$ & $(0.10)$ & $(0.65)$ \\
\hline \multirow[t]{2}{*}{ SalesGrowth } & 3.0355 & 0.6021 & 0.0198 & 0.5154 \\
\hline & $(1 ., 98)^{* *}$ & $(0.18)$ & $(0.17)$ & $(0.55)$ \\
\hline \multirow[t]{2}{*}{ CashFlow } & -0.0354 & 0.4593 & -0.5360 & -0.4198 \\
\hline & $(0.03)$ & $(0.11)$ & $(0.58)$ & $(0.30)$ \\
\hline \multirow[t]{2}{*}{ TotAsset } & -1.5784 & -0.3675 & -0.1465 & -0.0597 \\
\hline & $(2.95)^{* * *}$ & $(0.32)$ & $(0.37)$ & $(0.15)$ \\
\hline Obs. & 532 & 462 & 1551 & 1088 \\
\hline Year Dummies & Yes & Yes & Yes & Yes \\
\hline Ind. Dummies & Yes & Yes & Yes & Yes \\
\hline log likelihood & -300.78 & -178.85 & -516.79 & -375.65 \\
\hline
\end{tabular}


Table 9. Lending Supply (LS) on Subsequent Abnormal Capital Investments: the effects of ScaledWPS and HP Index

The dependent variable is abnormal capital investment (CI). Lending Supply (LS) is the ratio of the value of shares available supplied for lending and firm's market capitalization. HP index is calculated based on the methodology described in Hadlock and Pierce (2010). Following Edmans, Gabaix, and Landier (2009), we employ scaled wealthperformance sensitivity to capture the sensitivity of the manager's wealth to the stock price (ScaledWPS). This measure is the dollar change in the CEOs wealth for a 100 percentage point change in the stock price, scaled by annual pay. HP index is computed based on the methodology described in Hadlock and Pierce (2010). A firm is defined as a high (low) ScaledWPS firm if its ScaledWPS is above (below) the 67th (33rd) percentile of the ScaledWPS of the sample. A firm is defined as a high (low) HP Index firm if its HP Index is above (below) the 67th (33rd) percentile of the HP Index of the sample. Abnormal Capital Investments is defined following Titman et. al. (2004). TotAsset is the logarithm of total asset. BM is the logarithm of the book-to-market ratio. Leverage is the ratio of long term debt to total assets. CashFlow is the sum of income before extraordinary items and depreciation and amortization, scaled by total assets. ROA is the ratio of net income to total assets. All regressions control for year and firm fixed effects, whose coefficient estimates are suppressed. Heteroskedasticity-consistent standard errors clustered at the firm level. $t$-values are in parentheses. ${ }^{* * *}$, and $* * *$ indicate statistical significance at the $10 \%, 5 \%$, and $1 \%$ level, respectively.

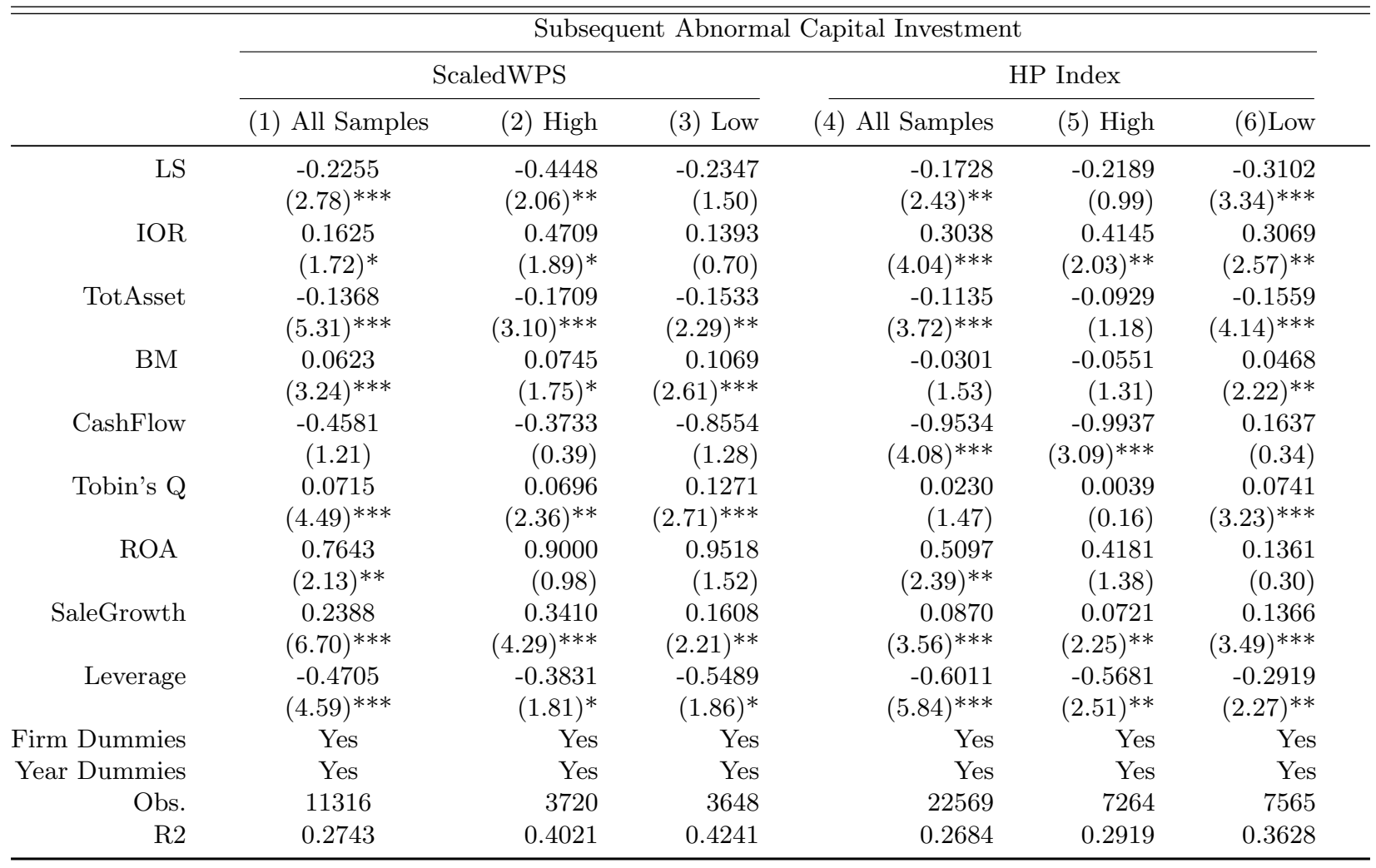


Table 10. Lending Supply (LS) and the Subsequent Mergers and Acquisition abnormal returns of acquirer firms: the effects of ScaledWPS and Payment method

LS is the ratio of the value of shares available supplied for lending and firm's market capitalization, which covers from 2002 to 2011. CAR $(-2,2)$ is the cumulative abnormal return calculated using a market model estimated over the period [-210, -11] relative to the announcement date (day 0). Lending Supply (LS) is the ratio of the value of shares available supplied for lending and firm's market capitalization. TotalAsset is logarithm of the item 6 in COMPUSTAT. Leverage is the ratio of long term debt to total assets. CashFlow is the sum of income before extraordinary items and depreciation and amortization, scaled by total assets. Firm value is calculated as the Tobin's $\mathrm{Q}$, the ratio of book value of assets minus book value of equity plus market value of equity to the book value of total assets. NonCashWorking is the difference between the current assets and the summation of the current liabilities and cash and cash equivalents, scaled by total assets. ROA is the ratio of net income to total assets. PastStockReturns is the compounded daily stock returns over previous year of the merger and acquisition. FreeCashFlow is the difference between operating income before depreciation and the summation of the interest expense, income taxes, and capital expenditure, scaled by total asset. FixedAsset is the ratio of PP\&E and sales. High-tech is a dummy variable equals to one when both acquirer and target are from the high-tech industries (from SDC), zero otherwise. FriendDeal is a dummy which equals to one if the attitude is friend (SDC), zero otherwise. CashDeal is a dummy variable which equals to one if the deal is all cash financed, otherwise zero. A firm is defined as a high (low) ScaledWPS firm if its ScaledWPS is above (below) the 67th (33rd) percentile of the ScaledWPS of the sample. All Cash Deal represents those deals that use $100 \%$ cash for payment as reported in SDC. Non All Cash Deal refers to the complement sample. Year dummies and two digit industry dummies are also used to control for industry effects, while their coefficients are omitted. Following Petersen (2009), standards errors are adjusted for two-way cluster adjusted for firm and year. $t$-values are in parentheses. ${ }^{*}, * *$, and $* * *$ indicate statistical significance at the $10 \%, 5 \%$, and $1 \%$ level, respectively.

\begin{tabular}{|c|c|c|c|c|c|c|}
\hline & \multicolumn{6}{|c|}{$\overline{\mathrm{CAR}(-2,2)}$} \\
\hline & \multicolumn{3}{|c|}{ ScaledWPS } & \multicolumn{3}{|c|}{ Cash Deal } \\
\hline & (1) All Samples & (2) Low & (3) High & (4) All Samples & (5) NonAllCashDeal & (6)AllCashDeal \\
\hline \multirow[t]{2}{*}{ LS } & 0.0525 & 0.2299 & 0.1123 & 0.0473 & 0.1285 & -0.0676 \\
\hline & $(2.48)^{* *}$ & $(1.80)^{*}$ & $(0.97)$ & $(1.91)^{*}$ & $(3.31)^{* * *}$ & $(1.52)$ \\
\hline \multirow[t]{2}{*}{ TotAsset } & -0.0066 & -0.0037 & -0.0066 & -0.0050 & -0.0066 & -0.0053 \\
\hline & $(2.57)^{* *}$ & $(0.64)$ & $(1.52)$ & $(4.72)^{* * *}$ & $(3.43)^{* * *}$ & $(2.58)^{* *}$ \\
\hline \multirow[t]{2}{*}{ PastStockReturn } & 0.0372 & 0.0779 & 0.0574 & 0.0192 & 0.0266 & 0.0120 \\
\hline & $(2.67)^{* * *}$ & $(2.58)^{* *}$ & $(1.70)^{*}$ & $(2.67)^{* * *}$ & $(2.79)^{* * *}$ & $(0.63)$ \\
\hline \multirow[t]{2}{*}{ ROA } & -0.0028 & 0.0917 & -0.0298 & -0.0266 & -0.0192 & -0.0589 \\
\hline & $(0.10)$ & $(1.00)$ & $(0.45)$ & $(1.03)$ & $(0.68)$ & $(1.82)^{*}$ \\
\hline \multirow[t]{2}{*}{ Tobin's Q } & -0.0001 & 0.0104 & 0.0170 & -0.0009 & 0.0020 & -0.0014 \\
\hline & $(0.03)$ & $(1.86)^{*}$ & $(1.52)$ & $(0.59)$ & $(0.63)$ & $(0.26)$ \\
\hline \multirow[t]{2}{*}{ FixedAsset } & 0.0710 & 0.0998 & 0.0853 & 0.0561 & 0.0645 & 0.0240 \\
\hline & $(2.21)^{* *}$ & $(1.28)$ & $(1.21)$ & $(2.34)^{* *}$ & $(2.38)^{* *}$ & $(0.65)$ \\
\hline \multirow[t]{2}{*}{$\mathrm{R} \& \mathrm{D}$} & -0.1307 & -0.0310 & -0.0596 & -0.1100 & -0.0938 & -0.0772 \\
\hline & $(2.32)^{* *}$ & $(0.32)$ & $(0.47)$ & $(2.35)^{* *}$ & $(1.30)$ & $(0.73)$ \\
\hline \multirow[t]{2}{*}{ NonCashWorking } & -0.0038 & -0.0017 & -0.0484 & 0.0054 & 0.0071 & -0.0021 \\
\hline & $(0.10)$ & $(0.03)$ & $(0.65)$ & $(0.34)$ & $(0.33)$ & $(0.07)$ \\
\hline \multirow[t]{2}{*}{ Leverage } & -0.0074 & -0.0949 & -0.0542 & -0.0032 & -0.0167 & -0.0033 \\
\hline & $(0.35)$ & $(1.69)^{*}$ & $(1.12)$ & $(0.19)$ & $(0.65)$ & $(0.16)$ \\
\hline \multirow[t]{2}{*}{ FreeCashFlow } & -0.0539 & -0.0123 & -0.1224 & 0.0363 & 0.0149 & 0.1864 \\
\hline & $(0.71)$ & $(0.05)$ & $(1.09)$ & $(0.67)$ & $(0.25)$ & $(1.75)^{*}$ \\
\hline \multirow[t]{2}{*}{ RelativeDealSize } & -0.0472 & -0.0664 & -0.0522 & -0.0115 & -0.0211 & 0.0398 \\
\hline & $(2.46)^{* *}$ & $(1.09)$ & $(3.04) * * *$ & $(0.73)$ & $(1.25)$ & $(1.05)$ \\
\hline \multirow[t]{2}{*}{ FriendlyDeal } & -0.0195 & 0.0294 & 0.0941 & 0.0133 & -0.0049 & 0.0061 \\
\hline & $(1.06)$ & $(0.55)$ & $(3.90)^{* * *}$ & $(0.69)$ & $(0.16)$ & $(0.49)$ \\
\hline \multirow[t]{2}{*}{ High-tech } & 0.0066 & -0.0012 & -0.0231 & 0.0044 & 0.0134 & 0.0033 \\
\hline & $(0.54)$ & $(0.05)$ & $(0.96)$ & $(0.54)$ & $(1.46)$ & $(0.33)$ \\
\hline \multirow[t]{2}{*}{ TenderOffer } & 0.0062 & 0.0089 & 0.0080 & -0.0001 & -0.0127 & -0.0032 \\
\hline & $(0.73)$ & $(0.61)$ & $(0.34)$ & $(0.01)$ & $(0.45)$ & $(0.37)$ \\
\hline \multirow[t]{2}{*}{ CashDeal } & 0.0078 & 0.0020 & 0.0011 & & & \\
\hline & $(1.01)$ & $(0.12)$ & $(0.08)$ & & & \\
\hline \multirow[t]{2}{*}{ IOR } & 0.0061 & -0.0185 & -0.0173 & 0.0054 & -0.0111 & 0.0372 \\
\hline & $(0.37)$ & $(0.47)$ & $(0.33)$ & $(0.54)$ & $(0.97)$ & $(1.99)^{* *}$ \\
\hline Year Dummies & Yes & Yes & Yes & Yes & Yes & Yes \\
\hline Ind Dummies & Yes & Yes & Yes & Yes & Yes & Yes \\
\hline Obs. & 541 & 178 & 179 & 968 & 582 & 386 \\
\hline$R^{2}$ & 0.2305 & 0.4181 & 0.3783 & 0.1096 & 0.1459 & 0.2367 \\
\hline
\end{tabular}


Table 11. Lending Supply (LS) and the Subsequent Firm Value: the effects of ScaledWPS and HP Index

LS is the ratio of the value of shares available supplied for lending and firm's market capitalization, which covers from 2002 to 2011. Firm value is referred to the industry adjusted Tobin's Q, the ratio of book value of assets minus book value of equity plus market value of equity to the book value of total assets and adjusted for the median of 2-digit industry. HP index is calculated based on the methodology described in Hadlock and Pierce (2010). Following Edmans, Gabaix, and Landier (2009), we employ scaled wealth-performance sensitivity to capture the sensitivity of the manager's wealth to the stock price (ScaledWPS). This measure is the dollar change in the CEOs wealth for a 100 percentage point change in the stock price, scaled by annual pay. A firm is defined as a high (low) ScaledWPS firm if its ScaledWPS is above (below) the 67th (33rd) percentile of the ScaledWPS of the sample. A firm is defined as a high (low) HP Index firm if its HP Index is above (below) the 67th (33rd) percentile of the HP Index of the sample. Size is the logarithm of market capitalization. Sale is logarithm of the sale. IOR is the ratio of the institutional ownership. Age is derived from the first date of the companys total assets data in Compustat. Leverage is the ratio of long term debt to total assets. CashFlow is the sum of income before extraordinary items and depreciation and amortization, scaled by total assets. Dividend is the ratio of dividend and book value of equity. ROE is the ratio of net income to book value of equity. $R \& D$ is ratio of $R \& D$ and total asset. FixedAsset is the ratio of PP\&E and sales. Capx is the ratio of capital expenditure to the total assets. Insider ownership is equal to the fraction of shares held by insiders, such as CEO, CFO, CO as well as president, to the total shares outstanding. All regressions are controlled for year and firm fixed effects, while coefficients are omitted. Heteroskedasticity-consistent standard errors are clustered at the firm level. $t$-values are in parentheses. ${ }^{*}, * *$, and $* * *$ indicate statistical significance at the $10 \%, 5 \%$, and $1 \%$ level, respectively.

\begin{tabular}{|c|c|c|c|c|c|c|}
\hline & \multicolumn{6}{|c|}{ Subsequent Firm Values } \\
\hline & \multicolumn{3}{|c|}{ ScaledWPS } & \multicolumn{3}{|c|}{ HP Index } \\
\hline & (1) All Samples & (2) High & (3) Low & (4) All Samples & (5) High & (6)Low \\
\hline \multirow[t]{2}{*}{ LS } & 0.1736 & 0.5536 & 0.0306 & 0.2194 & 0.1377 & 0.3209 \\
\hline & $(2.10)^{* *}$ & $(1.71)^{*}$ & $(0.30)$ & $(2.81)^{* * *}$ & $(0.54)$ & $(3.51)^{* * *}$ \\
\hline \multirow[t]{2}{*}{ IOR } & -0.0075 & -0.1897 & 0.0291 & -0.1601 & -0.6545 & 0.0923 \\
\hline & $(0.05)$ & $(0.54)$ & $(0.12)$ & $(1.51)$ & $(2.48)^{* *}$ & $(0.70)$ \\
\hline \multirow[t]{2}{*}{ Size } & 0.0638 & 0.1132 & -0.0034 & -0.0450 & -0.1706 & 0.0561 \\
\hline & $(2.31)^{* *}$ & $(1.55)$ & $(0.08)$ & $(2.11)^{* *}$ & $(4.02)^{* * *}$ & $(1.87)^{*}$ \\
\hline \multirow{2}{*}{ Sale } & -0.3906 & -0.5444 & -0.2205 & -0.2565 & -0.1799 & -0.3058 \\
\hline & $(6.32)^{* * *}$ & $(4.00)^{* * *}$ & $(2.08)^{* *}$ & $(5.27)^{* * *}$ & $(2.16)^{* *}$ & $(3.90)^{* * *}$ \\
\hline \multirow[t]{2}{*}{ Leverage } & -0.4492 & -0.3897 & -0.1022 & -0.4699 & -0.5136 & -0.4995 \\
\hline & $(3.01)^{* * *}$ & $(1.07)$ & $(0.47)$ & $(3.87)^{* * *}$ & $(1.70)^{*}$ & $(2.81)^{* * *}$ \\
\hline \multirow[t]{2}{*}{ CashFlow } & 0.3286 & 2.1454 & -0.3032 & -0.2276 & -0.3692 & 0.0526 \\
\hline & $(1.24)$ & $(3.57)^{* * *}$ & $(0.81)$ & $(1.66)^{*}$ & $(1.86)^{*}$ & $(0.28)$ \\
\hline \multirow[t]{2}{*}{ Age } & -0.2063 & -0.1179 & -0.1096 & -0.3331 & -0.5065 & -0.0481 \\
\hline & $(1.76)^{*}$ & $(0.39)$ & $(0.58)$ & $(4.28)^{* * *}$ & $(2.67)^{* * *}$ & $(0.47)$ \\
\hline \multirow{2}{*}{ Dividend } & -0.3177 & 0.3488 & -0.3077 & 0.0395 & 0.5020 & -0.0301 \\
\hline & $(1.35)$ & $(0.75)$ & $(0.95)$ & $(0.14)$ & $(0.64)$ & $(0.07)$ \\
\hline \multirow[t]{2}{*}{$\mathrm{R} \& \mathrm{D}$} & 315.5276 & 682.7516 & 198.8703 & -0.0378 & -0.9361 & -0.1998 \\
\hline & $(1.80)^{*}$ & $(2.46)^{* *}$ & $(1.05)$ & $(0.03)$ & $(0.71)$ & $(1.32)$ \\
\hline \multirow[t]{2}{*}{ FixedAsset } & -0.1606 & -0.1616 & -0.0812 & -0.0569 & -0.0072 & -0.0976 \\
\hline & $(3.23)^{* * *}$ & $(1.31)$ & $(1.08)$ & $(2.08)^{* *}$ & $(0.16)$ & $(2.75)^{* * *}$ \\
\hline \multirow[t]{2}{*}{ Capx } & 0.0489 & -0.0701 & -0.4131 & -0.0111 & -0.8690 & -0.4510 \\
\hline & $(0.16)$ & $(0.12)$ & $(0.59)$ & $(0.03)$ & $(1.36)$ & (1.18) \\
\hline \multirow[t]{2}{*}{ Cash } & -0.0326 & -0.0768 & 0.0064 & -0.0711 & -3.3677 & -0.0638 \\
\hline & $(2.56)^{* *}$ & $(2.73)^{* * *}$ & $(0.66)$ & $(3.04)^{* * *}$ & $(1.91)^{*}$ & $(3.09)^{* * *}$ \\
\hline \multirow{2}{*}{ InsiderOwn } & 0.6594 & 0.2001 & 0.2453 & 0.4768 & 0.3441 & -0.0041 \\
\hline & $(2.05)^{* *}$ & $(0.31)$ & $(0.51)$ & $(1.53)$ & $(0.61)$ & $(0.01)$ \\
\hline \multirow[t]{2}{*}{ InsiderOwn*2 } & -0.2598 & 0.5387 & -0.0844 & -0.4155 & -0.1405 & 0.4646 \\
\hline & $(0.95)$ & $(0.66)$ & $(0.25)$ & $(0.67)$ & $(0.13)$ & $(0.31)$ \\
\hline \multirow[t]{2}{*}{ ROE } & 0.1425 & -0.2701 & 0.2207 & 0.0713 & 0.0639 & 0.0739 \\
\hline & $(1.59)$ & $(1.50)$ & $(1.61)$ & $(1.30)$ & $(0.72)$ & $(1.07)$ \\
\hline Year Dummies & Yes & Yes & Yes & Yes & Yes & Yes \\
\hline Firm Dummies & Yes & Yes & Yes & Yes & Yes & Yes \\
\hline Obs. & 10423 & 3429 & 3400 & 22671 & 7216 & 7665 \\
\hline $\mathrm{R} 2$ & 0.7499 & 0.8186 & 0.7874 & 0.7172 & 0.7463 & 0.7201 \\
\hline
\end{tabular}


Table 12. The impact of SHO on the governance effect of Lending Supply (LS) on CI and Tobin's Q

This table presents the impact of the changes in short-selling regulation on the governance effect of lending supply (LS) on CI and Tobin's Q. Regulation SHO is announced by SEC in 2004. SEC randomly selects a sample of pilot securities and formally removes their price restrictions for short selling on January, 3, 2005. We employ Eq.(7) and Eq.(8), and this table includes the results. The sample is from 2002 till the end of the PILOT program (2007). SHO is a dummy variable which equals to one if the firm is selected as a Reg SHO pilot security during year 2004 to 2007, zero otherwise. LS is the ratio of the value of shares available supplied for lending and firm's market capitalization. Size is the logarithm of total asset. CashFlow is the sum of income before extraordinary items and depreciation and amortization, scaled by total assets. BM is the logarithm of the book-to-market ratio. Leverage is the ratio of long term debt to total assets. ROA is the ratio of net income to total assets. SaleGrowth is the changes in sales scaled by lagged sales. Sale is logarithm of the sale. IOR is the ratio of the institutional ownership. Age is derived from the first date of the companys total assets data in Compustat. Leverage is the ratio of long term debt to total assets. CashFlow is the sum of income before extraordinary items and depreciation and amortization, scaled by total assets. Dividend is the ratio of dividend and book value of equity. ROE is the ratio of net income to book value of equity. $R \& D$ is ratio of $R \& D$ and total asset. FixedAsset is the ratio of PP\&E and sale. Capx is ratio of capital expenditure and total assets. InsiderOwn is equal to the fraction of shares held by insiders, such as CEO, CFO, CO as well as president. All regressions are controlled for year and firm fixed effects, while coefficients are omitted. Heteroskedasticity-consistent standard errors are clustered at the firm and year level. $t$-values are in parentheses. ${ }^{*}, * *$, and $* * *$ indicate statistical significance at the $10 \%, 5 \%$, and $1 \%$ level, respectively.

\begin{tabular}{|c|c|c|c|c|}
\hline & \multicolumn{2}{|c|}{ Subsequent CI } & \multicolumn{2}{|c|}{ Subsequent Firm Values } \\
\hline & (1) & $(2)$ & (3) & (4) \\
\hline \multirow[t]{2}{*}{ LS } & -5.8421 & -4.8707 & 1.6960 & 1.9052 \\
\hline & $(3.86)^{* *}$ & $(4.50)^{* * *}$ & $(2.40)^{* *}$ & $(2.31)^{* *}$ \\
\hline \multirow[t]{2}{*}{ LS $\times$ Treated $\times$ Pilot } & -3.7144 & -3.9323 & 2.3353 & 2.0104 \\
\hline & $(2.59)^{* * *}$ & $(2.73)^{* * *}$ & $(2.02)^{* *}$ & $(2.06)^{* *}$ \\
\hline \multirow{2}{*}{ LS $\times$ Treated } & 3.8782 & 4.0099 & -2.0832 & -1.9665 \\
\hline & $(3.32)^{* * *}$ & $(3.11)^{* * *}$ & $(1.88)^{*}$ & $(2.33)^{* *}$ \\
\hline \multirow[t]{2}{*}{$\mathrm{LS} \times$ Pilot } & 5.6028 & 4.8134 & -1.6380 & -1.2632 \\
\hline & $(3.75)^{* * *}$ & $(4.59)^{* * *}$ & $(1.89)^{*}$ & $(1.98)^{* *}$ \\
\hline \multirow[t]{2}{*}{ Treated $\times$ Pilot } & 0.0656 & 0.0843 & -0.1241 & -0.1164 \\
\hline & $(1.41)$ & $(2.22)^{* *}$ & $(1.41)$ & $(1.18)$ \\
\hline \multirow[t]{2}{*}{ Pilot } & 0.1592 & 0.1390 & -0.0115 & 0.0333 \\
\hline & $(3.24)^{* * *}$ & $(2.87)^{* * *}$ & $(0.26)$ & $(0.29)$ \\
\hline \multirow[t]{2}{*}{ IOR } & 0.2849 & 0.2838 & -1.0975 & -0.6555 \\
\hline & $(2.72)^{* * *}$ & $(2.53)^{* *}$ & $(7.32)^{* * *}$ & $(5.14)^{* * *}$ \\
\hline \multirow[t]{2}{*}{ Size } & & -0.2248 & & 0.0868 \\
\hline & & $(1.00)$ & & $(0.97)$ \\
\hline \multirow[t]{2}{*}{ Leverage } & & -1.2660 & & -0.0493 \\
\hline & & $(6.17)^{* * *}$ & & $(0.70)$ \\
\hline \multirow[t]{2}{*}{$\mathrm{ROA}$} & & -0.1924 & & \\
\hline & & $(9.15)^{* * *}$ & & \\
\hline \multirow[t]{2}{*}{ Tobin's Q } & & 0.5740 & & \\
\hline & & $(2.80)^{* * *}$ & & \\
\hline \multirow[t]{2}{*}{$\mathrm{BM}$} & & 0.0146 & & \\
\hline & & $(0.28)$ & & \\
\hline \multirow[t]{2}{*}{ SaleGrowth } & & 0.0277 & & \\
\hline & & $(3.42)^{* * *}$ & & \\
\hline \multirow[t]{2}{*}{ CashFlow } & & & & -0.2894 \\
\hline & & & & $(0.91)$ \\
\hline \multirow[t]{2}{*}{$\mathrm{R} \& \mathrm{D}$} & & & & 0.0633 \\
\hline & & & & $(1.75)^{*}$ \\
\hline \multirow[t]{2}{*}{ FixedAsset } & & & & -0.0002 \\
\hline & & & & $(3.97)^{* * *}$ \\
\hline \multirow[t]{2}{*}{ Dividend } & & & & -0.1757 \\
\hline & & & & $(1.32)$ \\
\hline \multirow{2}{*}{ Sale } & & & & -0.3471 \\
\hline & & & & $(7.63)^{* * *}$ \\
\hline Age & & & & -0.4473 \\
\hline & & & & $(4.64)^{* * *}$ \\
\hline Capx & & & & -1.0798 \\
\hline & & & & $(1.76)^{*}$ \\
\hline Cash & & & & -0.0159 \\
\hline & & & & $(1.88)^{*}$ \\
\hline InsiderOwn & & & & 0.4705 \\
\hline & & & & $(3.72)^{* * *}$ \\
\hline InsiderOwn ${ }^{2}$ & & & & -0.0631 \\
\hline & & & & $(4.03)^{* * *}$ \\
\hline ROE & & & & 0.0226 \\
\hline & & & & $(0.27)$ \\
\hline Year Dummy & $\mathrm{Y}$ & $\mathrm{Y}$ & Y & $\mathrm{Y}$ \\
\hline Firm Dummy & $\mathrm{Y}$ & $\mathrm{Y}$ & Y & $\mathrm{Y}$ \\
\hline No. & 13178 & 13035 & 14625 & 14245 \\
\hline$R^{2}$ & 0.3664 & 0.3791 & 0.7335 & 0.7484 \\
\hline
\end{tabular}


Table 13. Results of Residual LS

This table presents the results using residual LS to re-test our major regression models. Residual LS is estimated by regress LS on contemporaneous firm size, book-to-market ratio, firm age, and institutional ownership ratio with firm and year fixed effect included. In column (1), the dependent variable is abnormal capital investment in the subsequent year. In column (2), the dependent variable is the 5-day cumulative abnormal returns (CAR) for acquirer firms. In column (3), the dependent variable is the subsequent Tobin's Q in the following year. In columns (1) and (3), we control for both year and firm fixed effect. In column (2), we control for both industry and year fixed effect. The detailed definitions of these variables are reported in Appendix B. We cluster standard errors at the firm and year level in column (2), and cluster standard errors at the firm level at columns (1) and (3). $t$-values are in parentheses. ${ }^{*}, * *$, and $* * *$ indicate statistical significance at the $10 \%, 5 \%$, and $1 \%$ level, respectively.

\begin{tabular}{|c|c|c|c|}
\hline & Subsequent CI & CAR $(-2,2)$ & Subsequent Firm Value \\
\hline \multirow[t]{2}{*}{ Abnormal LS } & -0.1344 & 0.0489 & 0.2295 \\
\hline & $(2.05)^{* *}$ & $(2.00)^{* *}$ & $(2.95)^{* * *}$ \\
\hline \multirow[t]{2}{*}{ IOR } & 0.2428 & 0.0136 & -0.1497 \\
\hline & $(3.34)^{* * *}$ & $(1.61)$ & $(1.42)$ \\
\hline \multirow[t]{2}{*}{ Size } & -0.1002 & -0.0055 & -0.0368 \\
\hline & $(3.67)^{* * *}$ & $(5.98)^{* * *}$ & $(1.76)^{*}$ \\
\hline \multirow[t]{2}{*}{ Leverage } & -0.6532 & -0.0050 & -0.4708 \\
\hline & $(6.67)^{* * *}$ & $(0.30)$ & $(3.87)^{* * *}$ \\
\hline \multirow[t]{2}{*}{ ROA } & 0.5340 & -0.0270 & \\
\hline & $(2.11)^{* *}$ & $(1.02)$ & \\
\hline \multirow[t]{2}{*}{ Tobin's Q } & 0.0227 & & \\
\hline & $(1.82)^{*}$ & & \\
\hline \multirow[t]{2}{*}{$\mathrm{BM}$} & -0.1111 & & \\
\hline & $(6.69)^{* * *}$ & & \\
\hline \multirow[t]{2}{*}{ SaleGrowth } & 0.0776 & & \\
\hline & $(3.16)^{* * *}$ & & \\
\hline \multirow[t]{2}{*}{ CashFlow } & -1.0202 & & -0.2237 \\
\hline & $(3.82)^{* * *}$ & & $(1.55)$ \\
\hline \multirow[t]{2}{*}{$R \& D$} & & -0.1073 & -0.3704 \\
\hline & & $(2.32)^{* *}$ & $(0.35)$ \\
\hline \multirow[t]{2}{*}{ FixedAsset } & & 0.0551 & -0.0650 \\
\hline & & $(2.28)^{* *}$ & $(2.41)^{* *}$ \\
\hline \multirow[t]{2}{*}{ Dividend } & & & 0.0710 \\
\hline & & & $(0.26)$ \\
\hline \multirow[t]{2}{*}{ Sale } & & & -0.2644 \\
\hline & & & $(5.45)^{* * *}$ \\
\hline \multirow[t]{2}{*}{ Age } & & & -0.3108 \\
\hline & & & $(4.04)^{* * *}$ \\
\hline \multirow[t]{2}{*}{ Capx } & & & -0.0442 \\
\hline & & & $(0.13)$ \\
\hline \multirow[t]{2}{*}{ Cash } & & & -0.0713 \\
\hline & & & $(3.05)^{* * *}$ \\
\hline \multirow[t]{2}{*}{ InsiderOwn } & & & 0.4468 \\
\hline & & & $(1.43)$ \\
\hline InsiderOwn*2 & & & -0.3617 \\
\hline & & & $(0.58)$ \\
\hline ROE & & & 0.0764 \\
\hline & & & $(1.26)$ \\
\hline PastStockReturn & & 0.0192 & \\
\hline & & $(2.77)^{* * *}$ & \\
\hline FreeCashFlow & & 0.0338 & \\
\hline & & $(0.61)$ & \\
\hline NonCashWorking & & 0.0048 & \\
\hline & & $(0.31)$ & \\
\hline RelativeDealSize & & -0.0083 & \\
\hline & & $(0.54)$ & \\
\hline FriendlyDeal & & 0.0141 & \\
\hline & & $(0.76)$ & \\
\hline High-tech & & 0.0053 & \\
\hline & & $(0.66)$ & \\
\hline TenderOffer & & -0.0025 & \\
\hline & & $(0.23)$ & \\
\hline CashDeal & & 0.0076 & \\
\hline & & $(1.87)^{*}$ & \\
\hline Year Dummies & Y & Y & $\mathrm{Y}$ \\
\hline Firm Dummies & Y & $\mathrm{N}$ & $\mathrm{Y}$ \\
\hline Industry Dummies & $\mathrm{N}$ & $\mathrm{Y}$ & $\mathrm{N}$ \\
\hline Obs. & 23916 & 966 & 22578 \\
\hline$R^{2}$ & 0.2585 & 0.1053 & 0.7185 \\
\hline
\end{tabular}


Table A-1 . Determinants of Lending Supply (LS)

This table presents the determinants of Lending Supply (LS). LS is the ratio of the value of shares available supplied for lending and firm's market capitalization, which covers from 2002 to 2011. Size is the logarithm of firms' market capitalization. BM is the logarithm of the ratio of the book value of equity divided by the market value of equity. IOR is the ratio of institutional investors ownership. Age is the first date of the companys total assets data in COMPUSTAT (logarithm). Leverage is the ratio of long term debt to total assets. InsiderOwnership is the fraction of shares held by insiders (CEO, CFO, CO, President). Idio Vol is the measure of idiosyncratic volatility based on Fama French three-factor model. Past Return is the compounded daily stock returns over previous year of the merger and acquisition (log). Illiq is the measure of illiquidity as proposed in Amihud (2002). CashFlow is the sum of income before extraordinary items and depreciation and amortization, scaled by total assets. Dividend is the ratio of dividend yield and total assets. $R \& D$ is the ratio of $R \& D$ and the total asset. ROE is the return on equity. AnalystsCov is the number of analysts. AnalystsDisp is the standard deviation of analysts forecasts scaled by the absolute mean forecasts. Columns (1), (2), and (3) use the contemporaneous LS as dependent variable. Models 4, 5, and 6 use the subsequent LS as dependent variable. Two digit industry dummies are also used to control for industry effects, while their coefficients are omitted. Constant is also omitted. Following Petersen (2009), standards errors are adjusted for two-way cluster adjusted for firm and year. $t$-values are in parentheses. ${ }^{*}, * *$, and $* * *$ indicate statistical significance at the $10 \%, 5 \%$, and $1 \%$ level, respectively.

\begin{tabular}{|c|c|c|c|c|c|c|}
\hline & \multicolumn{6}{|c|}{ Lending Supply } \\
\hline & \multicolumn{3}{|c|}{$L S_{i, t}$} & \multicolumn{3}{|c|}{$L S_{i, t-1}$} \\
\hline & (1) & $(2)$ & $(3)$ & (4) & (5) & (6) \\
\hline \multirow[t]{2}{*}{ SIZE } & -0.0166 & -0.0270 & -0.0463 & -0.0041 & -0.0111 & -0.0245 \\
\hline & $(2.18)^{* *}$ & $(2.29)^{* *}$ & $(2.02)^{* *}$ & $(0.96)$ & $(1.68)^{*}$ & $(2.52)^{* *}$ \\
\hline \multirow[t]{2}{*}{$\mathrm{BM}$} & 0.0019 & -0.0071 & -0.0154 & 0.0071 & 0.0009 & -0.0035 \\
\hline & $(0.62)$ & $(1.63)$ & $(1.49)$ & $(2.34)^{* *}$ & $(0.17)$ & $(0.40)$ \\
\hline \multirow[t]{2}{*}{ IOR } & 0.2298 & 0.2171 & 0.1459 & 0.2370 & 0.2260 & 0.1775 \\
\hline & $(3.61)^{* * *}$ & $(3.72)^{* * *}$ & $(3.20)^{* * *}$ & $(5.81)^{* * *}$ & $(6.07)^{* * *}$ & $(4.41)^{* * *}$ \\
\hline \multirow[t]{2}{*}{ Age } & 0.0096 & 0.0057 & 0.0040 & 0.0086 & 0.0063 & 0.0087 \\
\hline & $(3.63)^{* * *}$ & $(2.35)^{* *}$ & $(1.60)$ & $(1.91)^{*}$ & $(1.79)^{*}$ & $(1.45)$ \\
\hline \multirow[t]{2}{*}{ Leverage } & 0.0125 & -0.0192 & -0.0181 & -0.0188 & -0.0413 & -0.0394 \\
\hline & $(0.55)$ & $(1.82)^{*}$ & $(1.49)$ & $(2.09)^{* *}$ & $(3.43)^{* * *}$ & $(2.29)^{* *}$ \\
\hline \multirow[t]{2}{*}{ InsiderOwnership } & 0.0007 & -0.0005 & -0.0207 & 0.0071 & 0.0046 & -0.0159 \\
\hline & $(0.11)$ & $(0.08)$ & (1.06) & $(0.97)$ & $(0.71)$ & $(1.18)$ \\
\hline \multirow[t]{2}{*}{ Idio_Vol } & -0.0832 & -0.1039 & 0.2048 & 0.1500 & 0.1753 & 1.5059 \\
\hline & $(0.35)$ & $(0.53)$ & $(1.05)$ & $(0.77)$ & $(0.79)$ & $(0.90)$ \\
\hline \multirow[t]{2}{*}{ Past_Return } & 0.0010 & 0.0017 & 0.0045 & & & \\
\hline & $(0.38)$ & $(0.52)$ & $(0.84)$ & & & \\
\hline \multirow[t]{2}{*}{ Illiq } & 0.0003 & -0.0007 & 0.0016 & -0.0046 & -0.0055 & -0.0023 \\
\hline & $(0.19)$ & $(0.64)$ & $(0.74)$ & $(3.77)^{* * *}$ & $(4.13) * * *$ & $(2.50)^{* *}$ \\
\hline \multirow[t]{2}{*}{ CashFlow } & & -0.0507 & -0.0157 & & -0.0206 & 0.0038 \\
\hline & & $(1.95)^{*}$ & $(0.49)$ & & $(1.65)^{*}$ & $(0.19)$ \\
\hline \multirow[t]{2}{*}{ Dividend } & & 0.0001 & 0.0003 & & 0.0016 & 0.0023 \\
\hline & & $(0.12)$ & $(0.31)$ & & $(2.21)^{* *}$ & $(2.01)^{* *}$ \\
\hline \multirow[t]{2}{*}{$\mathrm{R} \& \mathrm{D}$} & & 0.0000 & 0.4495 & & 0.0001 & 0.1312 \\
\hline & & $(0.00)$ & $(1.55)$ & & $(2.14)^{* *}$ & $(0.37)$ \\
\hline \multirow[t]{2}{*}{ PP\&E } & & 0.0049 & 0.0002 & & 0.0068 & 0.0037 \\
\hline & & $(0.79)$ & $(0.04)$ & & $(2.12)^{* *}$ & $(0.60)$ \\
\hline \multirow[t]{2}{*}{$\mathrm{ROE}$} & & -0.0000 & -0.0171 & & -0.0001 & -0.0060 \\
\hline & & $(0.54)$ & $(1.27)$ & & $(1.81)^{*}$ & $(1.41)$ \\
\hline \multirow[t]{2}{*}{ Sale } & & 0.0162 & 0.0246 & & 0.0118 & 0.0175 \\
\hline & & $(2.28)^{* *}$ & $(1.92)^{*}$ & & $(2.44)^{* *}$ & $(1.85)^{*}$ \\
\hline \multirow[t]{2}{*}{ AnalystsCov } & & & 0.0016 & & & -0.0002 \\
\hline & & & $(2.09)^{* *}$ & & & $(0.30)$ \\
\hline \multirow[t]{2}{*}{ AnalystsDisp } & & & 0.1305 & & & 0.3857 \\
\hline & & & $(0.91)$ & & & $(5.66) * * *$ \\
\hline Year Dummy & Yes & Yes & Yes & Yes & Yes & Yes \\
\hline Ind Dummy & Yes & Yes & Yes & Yes & Yes & Yes \\
\hline No. & 18154 & 18014 & 7004 & 18734 & 18582 & 7108 \\
\hline $\mathrm{R}^{2}$ & 0.5210 & 0.5355 & 0.6409 & 0.4596 & 0.4759 & 0.5065 \\
\hline
\end{tabular}




\section{References}

Amihud, Y. (2002). Illiquidity and stock returns: cross-section and time-series effects. Journal of Financial Markets, 5(1), 31-56.

Asquith, P., Pathak, P. A., \& Ritter, J. R. (2005). Short interest, institutional ownership, and stock returns. Journal of Financial Economics, 78(2), 243-276.

Bebchuk, L. A., Cohen, A., \& Ferrell, A. (2009). What Matters in Corporate Governance? Review of Financial Studies, 22(2), 783-827.

Bertrand, M., \& Mullainathan, S. (2003). Enjoying the quiet life? corporate governance and managerial preferences. Journal of Political Economy, 111(5).

Billett, M. T., Garfinkel, J. A., \& Jiang, Y. (2011). The influence of governance on investment: Evidence from a hazard model. Journal of Financial Economics, 102(3), 643-670.

Boehmer, E., Jones, C. M., \& Zhang, X. (2008). Which shorts are informed? Journal of Finance, $63(2), 491-527$.

Boehmer, E., \& Wu, J. J. (2012). Short selling and the price discovery process. Review of Financial Studies forthcoming.

Bond, P., Edmans, A., \& Goldstein, I. (2011). The real effects of financial markets. National Bureau of Economic Research.

Bris, A., Goetzmann, W. N., \& Zhu, N. (2007). Efficiency and the bear: Short sales and markets around the world. Journal of Finance, 62(3), 1029-1079.

Chang, E. C., Cheng, J. W., \& Yu, Y. (2007). Short Sales constraints and price discovery: Evidence from the hong kong market. Journal of Finance, 62(5), 2097-2121.

Chang, E. C., Lin, T.-C., \& Ma, X. (2012). Governance through trading: Does institutional trading discipline empire building and earnings management? Working Paper.

Chen, T., Harford, J., \& Lin, C. (2012). Do financial analysts play a monitoring role? evidence from natural experiments. Working Paper.

Christophe, S. E., Ferri, M. G., \& Angel, J. J. (2004). Short-Selling prior to earnings announcements. Journal of Finance, 59(4), 1845-1876.

Desai, H., Krishnamurthy, S., \& Venkataraman, K. (2006). Do short sellers target firms with poor earnings quality? evidence from earnings restatements. Review of Accounting Studies, 11, 71-90.

Diamond, D. W., \& Verrecchia, R. E. (1987). Constraints on short-selling and asset price adjustment to private information. Journal of Financial Economics, 18, 277-311.

Diether, K. B., Lee, K.-H., \& Werner, I. M. (2009). It's SHO time! short-sale price tests and market quality. The Journal of Finance, 64(1), 37-73.

Edmans, A., Gabaix, X., \& Landier, A. (2009). A multiplicative model of optimal CEO incentives in market equilibrium. Review of Financial Studies, 22(12), 4881-4917.

Edmans, A., Goldstein, I., \& Jiang, W. (2012). The real effects of financial markets: The impact of prices on takeovers. Journal of Finance Forthcoming.

Engelberg, J. E., Reed, A. V., \& Ringgenberg, M. C. (2012). How are shorts informed?: Short sellers, news, and information processing. Journal of Financial Economics, Forthcoming.

Fang, V. W., Huang, A., \& Karpoff, J. M. (2013). Short selling and earnings management: A controlled experiment. Working Paper.

Fu, F., Lin, L., \& Officer, M. S. (2013). Acquisitions driven by stock overvaluation: Are they good deals? Journal of Financial Economics Forthcoming.

Goldstein, I., \& Guembel, A. (2008). Manipulation and the allocational role of prices. Review of Economic Studies, 75(1), 133-164. 
Gompers, P., Ishii, J., \& Metrick, A. (2003). Corporate governance and equity prices. Quarterly Journal of Economics, 118(1), 107-155.

Gompers, P., \& Metrick, A. (2001). Institutional investors and equity prices. Quarterly Journal of Economics, 116(1), 229-259.

Hadlock, C. J., \& Pierce, J. R. (2010). New evidence on measuring financial constraints: Moving beyond the KZ index. Review of Financial Studies, 23(5), 1909-1940.

Hau, H., \& Lai, S. (2012). Real effects of stock underpricing. Journal of Financial Economics Forthcoming.

Henry, T. R., \& Koski, J. L. (2010, December). Short selling around seasoned equity offerings. Review of Financial Studies, 23(12), 4389-4418.

Jensen, M. (1986). Agency costs of free cash flow, corporate finance, and takeovers. American Economic Review, 76(2), 323-329.

Jensen, M. (2005). Agency costs of overvalued equity. Financial Management, 34 (1), 5-19.

Jensen, M., \& Meckling, W. H. (1976). Theory of the firm: Managerial behavior, agency costs and ownership structure. Journal of financial economics, 3(4), 305-360.

Karpoff, J. M., \& Lou, X. (2010). Short sellers and financial misconduct. Journal of Finance, $65(5), 1879-1913$.

Kim, E. H., \& Lu, Y. (2011). CEO ownership, external governance, and risk-taking. Journal of Financial Economics, 102(2), 272-292.

Massa, M., Zhang, B., \& Zhang, H. (2012). The invisible hand of short-selling: Does short-selling discipline earnings manipulation? Working Paper.

Masulis, R. W., Wang, C., \& Xie, F. (2007). Corporate governance and acquirer returns. Journal of Finance, 62(4), 1851-1889.

Meyer, B. (1990). Unemployement insurance and unemployement spells. Econometrica, 58, 757782.

Morck, R., Shleifer, A., \& Vishny, R. W. (1990). Do managerial objectives drive bad acquisitions? Journal of Finance, 45(1), 31-48.

Petersen, M. A. (2009). Estimating standard errors in finance panel data sets: Comparing approaches. Review of Financial Studies, 435-480.

Richardson, S. (2006). Over-investment of free cash flow. Review of Accounting Studies, 11(2), 159-189.

Saffi, P. A. C., \& Sigurdsson, K. (2011). Price efficiency and short selling. Review of Financial Studies, $24(3), 821-852$.

Titman, S., Wei, K., \& Xie, F. (2004). Capital investments and stock returns. Journal of Financial and Quantitative Analysis, 39(4), 677-700.

Whited, T. (2006). External finance constraints and the intertemporal pattern of intermittent investment. Journal of Financial Economics, 81(3), 467-502.

Yan, X. S., \& Zhang, Z. (2009). Institutional investors and equity returns: Are short-term institutions better informed? Review of Financial Studies, 22(2), 893-924. 